\title{
DESAIN KURIKULUM PAK ANAK USIA 9-12 TAHUN DI SINODE GEREJA KRISTEN PROTESTAN SIMALUNGUN (GKPS) DENGAN MENGGUNAKAN TEORI WYCKOFF
}

\author{
Yenni Septiani Purba \\ Yenni_Pur87@yahoo.com \\ Djoys Anneke Rantung \\ Universitas Kristen Indonesia \\ Djoys.anneke@gmail.com
}

\begin{abstract}
Abstrak
Penelitian ini bertujuan untuk mengetahui apa yang dimaksud dengan PAK Anak usia 9-12 tahun, bagaimana desain kurikulum PAK Anak di sinode GKPS selama ini, dan bagaimana mendesain kurikulum PAK Anak usia 9-12 tahun di sinode GKPS berdasarkan teori Wyckoff. Penelitian menggunakan metode penelitian deskriptif kualitatif melalui penelitian pustaka dan penelitian lapangan. Penelitian lapangan dilakukan dengan metode wawancara. Sampel ditetapkan menggunakan model sampel bertujuan (purposive sampling). Responden dalam penelitian ini berjumlah empat belas orang, yang terdiri dari delapan orang kepengurusan tingkat sinodal GKPS di Pematangsiantar dan enam orang kepengurusan yang berhubungan dengan Sekolah Minggu di jemaat GKPS Cengkareng, Jakarta. Data dari wawancara tersebut dianalisis dengan model deskripsi analisis.

Dari hasil penelitian ditemukan bahwa pemahaman GKPS tentang PAK Anak sudah memadai namun pelaksanaan PAK Anak di jemaat masih terbatas. Ditemukan data bahwa peraturan pembagian kelas Sekolah Minggu di GKPS belum konsisten. GKPS juga belum memiliki kurikulum PAK Anak. Bahan pengajaran yang ada hanya Buku Pedoman Pembelajaran Aku Gereja, yang sebenarnya bukan kurikulum. Ada beberapa faktor yang menyebabkan masalah ini: pertama, GKPS terbentur dengan bahan atau teks pengajaran Sekolah Minggu yang sudah ditetapkan oleh gereja-gereja anggota Sekretariat Bersama UEM. Kedua, belum ada ahli PAK Anak yang bertugas secara penuh dalam kepengurusan sinodal GKPS, dan faktor-faktor lainnya. Berdasarkan penelitian, kurikulum merupakan hal yang penting dan sangat dibutuhkan dalam PAK Anak. Menurut Wyckoff, kurikulum disusun berdasarkan kaitan antara beberapa unsur dasar, yaitu konteks, ruang lingkup, tujuan, dan proses. Berdasarkan teori Wyckoff tersebut, dalam penelitian ini, peneliti mendesain kurikulum PAK Anak usia 9-12 tahun di sinode GKPS.
\end{abstract}

Kata kunci: Pendidikan Agama Kristen, anak, desain, kurikulum, teori Wyckoff 


\section{A. Pendahuluan}

Sekolah Minggu adalah bagian yang sangat penting di dalam sebuah jemaat. Sekolah Minggu bukan hanya gereja masa depan melainkan sudah menjadi anggota gereja masa kini. Gereja menyediakan Sekolah Minggu sebagai wadah pengajaran Pendidikan Agama Kristen (PAK) bagi anak-anak. Sekolah Minggu memiliki peran yang sangat strategis untuk memperlengkapi anak dalam proses pengajaran ke arah pengenalan tentang rencana dan kehendak Allah. Menurut penulis, proses ini sangat penting mengingat perilaku sebagian anak-anak zaman sekarang (yang sering disebut anak zaman now) yang semakin lama semakin memprihatinkan; yang mana sebagian anak cenderung malas belajar, lebih tertarik main game, pergaulan yang cenderung bebas, untuk pergi ke gereja harus disuruh orangtua, Anak Sekolah Minggu sudah banyak yang memakai handphone ke gereja (kalau tidak memiliki handphone dianggap tidak gaul), dan lain-lain. Pengetahuan Agama Kristen anak juga sangat minim. Saat melakukan tugas dari sekolah untuk menulis ringkasan khotbah dalam buku catatan khotbah dari sekolahnya setiap kebaktian Minggu, anak hanya menulis judul perikopnya saja. Mereka tidak mampu menuliskan catatan mengenai gambaran atau deskripsi khotbah di dalam buku catatan (notes book) mereka.

Keprihatinan penulis terhadap masalah PAK Anak semakin besar setelah mengamati PAK Anak di beberapa tempat basis pelayanan gereja di mana penulis melayani sebagai pendeta, yaitu di Gereja Kristen Protestan Simalungun (GKPS). Di berbagai tempat di Indonesia, anak-anak Kristen belajar PAK dari guru-guru yang tidak berlatar belakang PAK. PAK di tengah-tengah keluarga juga merosot. Oleh karena itu sangat diperlukan PAK Anak melalui Sekolah Minggu.
PAK Anak akan berjalan dengan baik dengan adanya kurikulum. Kurikulum perlu disusun sesuai dengan kebutuhan dan perkembangan anak dengan jenjang usia tertentu. Namun, sayangnya belum ada kurikulum PAK Anak yang baku di sinode GKPS. Bahkan, belum ada juga penanganan khusus dari sinode GKPS untuk ASM. Hal ini ditunjukkan dengan belum adanya pelayan penuh waktu yang fokus pada PAK Anak di kepengurusan tingkat Sinode GKPS. Pelayan penuh waktu yang ada menangani pelayanan untuk seluruh kategori (kategori anak, pemuda, bapak, dan wanita), belum ada yang menangani PAK Anak secara khusus. Memang tidak dipungkiri, ada Kepengurusan Pusat Seksi Sekolah Minggu di sinode GKPS, namun mereka lebih condong berperan dalam struktur organisasinya. Selain itu, mereka yang ada di dalam kepengurusan itu tidak memiliki latar belakang PAK untuk Anak. Selain itu, gereja juga relatif jarang melakukan pembinaan-pembinaan untuk para GSM dan Pengurus SM, baik di tingkat jemaat, resort, distrik dan pusat.

Mengenai kategori usia, menurut Elizabeth B. Hurlock, anak adalah manusia dari kelompok usia 0 sampai 12 tahun. Masa anak-anak dapat dibagi dalam beberapa masa; masa bayi baru lahir (neonatal, dimulai dengan pemotongan dan pengikatan tali pusar sampai sekitar akhir minggu kedua), masa bayi (mulai dari usia dua minggu sampai usia dua tahun), awal masa anak-anak (usia dua tahun sampai enam tahun), dan akhir masa anak-anak. Akhir masa kanak (late childhood) berlangsung dari usia enam sampai tiba saatnya seseorang menjadi 
matang secara seksual. ${ }^{1}$ Setiap jenjang usia ini memiliki kebutuhan dan perkembangan yang berbeda-beda, baik secara fisik, moral, iman, dan lain-lain. Oleh karena itu, kurikulum perlu disusun sesuai dengan kebutuhan dan perkembangan anak dengan jenjang usia tertentu. Dalam penelitian ini, penulis membuat fokus penelitian pada kurikulum PAK Anak usia 9-12 tahun. Alasan yang esensial untuk memilih usia ini adalah karena usia ini secara umum dikenal sebagai usia pencarian identitas.

Menurut James Fowler, anak usia ini berada dalam tahap mencari dan menemukan iman. Iman mereka berkembang melalui apa yang mereka alami secara pribadi dalam relasi mereka dengan kelompok. Selain itu, iman mereka juga berkembang melalui cerita-cerita yang mereka dengar dari orang lain. ${ }^{2}$ Tentu Gereja memiliki tanggung jawab untuk membina anak usia 9-12 tahun dalam masa penemuan identitas dan iman ini. Selain itu, seperti sudah disampaikan sebelumnya, bahwa anak relatif kurang mendapatkan PAK yang baik dari keluarga atau sekolah. Oleh karena itu, PAK Anak di Gereja adalah wadah yang paling diharapkan untuk memberikan PAK yang baik bagi pembentukan dan pertumbuhan iman mereka. Hal ini yang mendasari penulis untuk memilih usia ini secara spesifik, dan menyusun kurikulum PAK untuk anak usia 9-12 tahun. Sementara, GKPS belum memiliki kurikulum untuk PAK Anak. Dari sejumlah latar belakang masalah yang sudah dipaparkan di atas, maka penulis termotivasi untuk melakukan penelitian dan menyusun penelitian dengan judul "Desain Kurikulum PAK Anak Usia 9-12 tahun di

\footnotetext{
${ }^{1}$ Elizabeth B. Hurlock, Psikologi Perkembangan: Suatu Pendekatan Sepanjang Rentang Kehidupan Edisi Kelima (Jakarta: Erlangga, 1980), 14.

2 James W. Fowler, Stages of Faith: The Psychology of Human Development and the Quest
}

Sinode Gereja Kristen Protestan Simalungun (GKPS) dengan Menggunakan Teori Wyckoff."

Dalam proses desain kurikulum ini, penelitian dibatasi hanya pada kurikulum PAK Anak usia 9-12 tahun. Pembatasan usia ini dilakukan mengingat pada usia tersebut, anak menjalani masa akhir anak dan akan memasuki masa remaja. Dengan pembatasan usia, kurikulum yang disusun akan lebih fokus dan sesuai dengan kebutuhan psikologis yang lebih spesifik bagi anak usia 9-12 tahun tersebut. Penulis mengikuti pembatasan usia menurut Ruth Kadarmanto, di mana anak-anak usia 9-12 tahun tersebut biasanya disebut Kelas Besar. $^{3}$

Oleh karena itu, penulis mendesain kurikulum PAK Anak untuk sinode GKPS khusus untuk usia 9-12 tahun, berpedoman pada prinsip-prinsip kurikulum yang dikembangkan oleh D. Campbell Wyckoff dalam bukunya yang berjudul Theory and Design of Christian Education Curriculum. Dari hasil penelitian pustaka serta wawancara, Penulis menindaklanjuti dengan menyusun kurikulum PAK Anak GKPS Usia 9-12 tahun. Kurikulum dibatasi hanya untuk lingkup pembelajaran satu tahun pertama (bulan Januari-Desember) untuk tahun ajaran 2020.

\section{B. Landasan Teori}

1. Hakikat Pendidikan Agama Kristen (PAK) Anak

\section{a. Pendidikan Agama Kristen}

Menurut Groome, "PAK adalah kegiatan politis bersama para peziarah

for Meaning (San Fransisco: Harper \& Cow, 1981), 131.

${ }^{3}$ Ruth S. Kadarmanto, Tuntunlah ke Jalan yang Benar: Panduan Mengajar Anak di Jemaat (Jakarta: BPK Gunung Mulia, 2012), 50. 
dalam waktu yang secara sengaja bersama mereka memberi perhatian pada kegiatan Allah di masa kini kita, pada cerita komunitas iman Kristen dan visi Kerajaan Allah, benih-benih yang telah hadir di antara kita." 4 Hakikat PAK menurut Groome ini menunjukkan bahwa PAK memiliki pengaruh terhadap pihak-pihak yang terhubung dengannya (baik naradidik maupun pendidik) untuk dapat memahami Allah yang berkarya sepanjang sejarah (sepanjang masa). Pengertian PAK ini menyadarkan kembali panggilan setiap umat Kristen menjadi Gereja Kristen yang universal. ${ }^{5}$ Penulis menyetujui pendapat Groome dan memilih untuk menggunakan istilah Pendidikan Agama Kristen (PAK).

Sementara, menurut D. Campbell Wyckoff, PAK adalah pendidikan yang menyadarkan setiap orang akan Allah dari kasih-Nya dalam Yesus Kristus, agar mereka mengetahui diri mereka yang sebenarnya, keadaannya, bertumbuh sebagai anak Allah dalam persekutuan Kristen, memenuhi panggilan bersama sebagai murid Yesus Kristus di dunia dan tetap percaya pada pengharapan Kristiani. ${ }^{6}$ Selanjutnya, Dien Sumiyatiningsih, yang mengutip pandangan Wyckoff, meringkas beberapa asas yang menjadi panduan dalam melaksanakan PAK, baik dalam teori maupun dalam praktik. Asas-asas tersebut menegaskan kepada pengelola, pendidik, dan peserta didik bahwa apabila mereka memusatkan pikiran dan pelayanan pada unsur-unsur tersebut, maka PAK akan terlaksana dengan baik. Asas-asas tersebut, yaitu:

- Alkitab sebagai pembimbing. Maksudnya, Alkitab merupakan dasar PAK.

4 Thomas H. Groome, Christian Religious Education: Pendidikan Agama Kristen Berbagi Cerita dan Visi Kita (Jakarta: BPK Gunung Mulia, 2017), 37.

${ }^{5}$ Ibid., 35-36.
- PAK memecahkan masalah kehidupan. Pendidikan yang relevan seharusnya dapat membantu peserta didik memecahkan masalah-masalah yang penting dalam kehidupannya.

- PAK memberi perhatian kepada peserta didik. Kebutuhan maupun pengalaman peserta didik yang selalu mengalami perubahan sesuai kondisinya menjadi suatu panduan untuk mendesain kurikulum yang sesuai dengan pengalaman dan kebutuhan mereka.

- Unsur Jemaat adalah wadah di mana kegiatan pelayanan jemaat bagi Tuhan dan sesama menjadi panggilan utama.

- Unsur Injil Yesus Kristus sebagai pernyataan Allah sekaligus sebagai kunci untuk memahami makna sejarah dan keberadaan manusia. Di samping itu, Tuhan Yesus diakui sebagai pusat Firman Allah dan alasan keberadaan Gereja. $^{7}$

Berdasarkan beberapa definisi PAK dan asas yang menjadi panduan pelaksanaan PAK di atas, dapat disimpulkan bahwa PAK adalah kegiatan pengajaran nilai-nilai yang diwariskan Kristus kepada para pengikut-Nya. Kegiatan pengajaran mengenai nilai-nilai Kristiani ini sangat kompleks, yang perlu dilakukan di tengah-tengah keluarga, di sekolah, maupun di gereja. Dalam penelitian ini, PAK yang dibahas adalah PAK yang dilakukan di Gereja. PAK dalam Gereja dilihat sebagai sebuah gambaran pendidikan yang membutuhkan relasi yang khas antara guru dan murid. Kekhasan relasi tersebut dibentuk oleh komitmen bersama untuk mempelajari berbagai hal, antara lain tugas panggilan Gereja, kasih, ketaatan kepada Tuhan,

${ }^{6}$ D. Campbell Wyckoff, Theory and Design of Christian Education Curriculum (Philadelphia: The Westminster Press, 1961), 21-22.

${ }^{7}$ Dien Sumiyatiningsih, Mengajar dengan Kreatif dan Menarik (Yogyakarta: Andi, 2006), 5. 
persekutuan dengan sesama, dan lain-lain. Hal-hal yang berhubungan dan dipelajari dalam PAK di dalam penelitian ini adalah tugas panggilan gereja dalam bidang pengajaran nilai-nilai kekristenan kepada warga jemaat yang masih anak-anak, khususnya anak-anak berusia 9-12 tahun.

\section{b. Anak Usia 9-12 Tahun}

Menurut Elizabeth B. Hurlock, anak adalah manusia dari kelompok usia 0 sampai 12 tahun. Masa anak-anak dapat dibagi dalam beberapa masa; masa bayi baru lahir (neonatal, dimulai dengan pemotongan dan pengikatan tali pusar sampai sekitar akhir minggu kedua), masa bayi (mulai dari usia dua minggu sampai usia dua tahun), awal masa anak-anak (usia dua tahun sampai enam tahun), dan akhir masa anak-anak. Akhir masa kanak (late childhood) berlangsung dari usia enam sampai tiba saatnya seseorang menjadi matang secara seksual. ${ }^{8}$

Pelayanan yang dilakukan gereja harus mempertimbangkan kehidupan manusia yang berbeda tiap kategori usia. Perbedaan kategori berarti perbedaan tugas-tugas perkembangan yang berujung pada masalah, minat dan kebutuhan yang berbeda-beda pula. ${ }^{9}$ Seorang pendidik perlu memerhatikan perkembangan anak agar dapat mendidik mereka dengan baik. Secara psikologis, menurut Erik Erikson, dikutip oleh Elizabeth B. Hurlock, anak usia 9-12 tahun termasuk pada akhir masa kanak-kanak. ${ }^{10}$ Sementara, menurut Singgih D. Gunarsa, anak usia 9-12 tahun

\footnotetext{
${ }^{8}$ Elizabeth B. Hurlock, Psikologi Perkembangan: Suatu Pendekatan Sepanjang Rentang Kehidupan Edisi Kelima (Jakarta: Erlangga: 1980), 14.

${ }^{9}$ Mariska Lauterboom, Perkembangan Anak dan Remaja serta Implikasinya bagi PAK di Konteks Gereja (Jurnal Theologia Universitas Kristen Satya Wacana, Salatiga, 2014).

${ }^{10}$ Elizabeth B. Hurlock, Psikologi Perkembangan: Suatu Pendekatan Sepanjang Rentang Kehidupan Edisi Kelima (Jakarta: Erlangga: 1980), 14.
}

disebut juga masa anak tanggung atau masa pra-remaja. ${ }^{11}$ Idealnya pertumbuhan psikologis yang terjadi pada anak usia ini adalah munculnya kemampuan diri. Anak tertarik untuk melakukan aktivitas yang bernilai kompetensi di antara teman-teman sekolah, teman-teman gereja dan tetangga. Erikson juga mengatakan, bila lingkungan mendukung, maka mereka akan menjadi anak yang kreatif berkarya. Sebaliknya, jika lingkungan tidak mendukung, maka mereka akan menjadi anak yang rendah diri. $^{12}$

Selain itu, ahli pendidikan, James Kenny dan Mary Kenny, mengatakan bahwa anak berusia sekitar 9-12 tahun merupakan usia yang aktif dan suka melakukan berbagai kegiatan. Mereka juga dapat mengerjakan suatu tugas, baik secara sendiri maupun berkelompok. Mereka hanya perlu diberi motivasi agar lebih percaya diri. Oleh karena itu, guru perlu menciptakan suasana yang mendukung sedemikian rupa sehingga anak dapat berhasil, kemudian memperhatikan dan menghargai keberhasilan tersebut. Memang tidak dapat dipungkiri bahwa seorang anak mungkin saja gagal dalam suatu jenis kegiatan. Namun, guru dapat mengembangkan kepercayaan diri anak melalui kegiatankegiatan yang lain yang efektif dan mendukung kepercayaan diri anak. ${ }^{13}$

Hurlock mengatakan, masa akhir anak-anak ditandai oleh kondisi yang sangat mempengaruhi perkembangan sosial anak. Pada usia 9-12 tahun ini, anak

\footnotetext{
${ }^{11}$ Singgih D. Gunarsa dan Yulia Singgih D. Gunarsa, Psikologi Praktis: Anak, Remaja dan Keluarga (Jakarta: BPK Gunung Mulia, 1995), 13. ${ }^{12}$ Elizabeth B. Hurlock, Psikologi Perkembangan: Suatu Pendekatan Sepanjang Rentang Kehidupan Edisi Kelima (Jakarta: Erlangga: 1980), 13.

${ }^{13}$ James Kenny dan Mary Kenny, Dari Bayi Sampai Dewasa: Uraian Praktis yang Membahas Pendidikan Anak Sesuai Dengan Tahap-tahap Perkembangannya (Jakarta: BPK Gunung Mulia, 1991), 254-255.
} 
lebih banyak dipengaruhi oleh temanteman sebaya daripada oleh orangtua dan anggota keluarga lainnya. Usia ini dikenal sebagai usia berkelompok dan anak mendapat dukungan dari teman sebaya atau kelompoknya. ${ }^{14}$

Selanjutnya, anak juga mengalami pertumbuhan dan perkembangan secara fisik. Pertumbuhan dan perkembangan tersebut dipengaruhi oleh kesehatan dan gizi. Semakin baik kesehatan dan gizinya, anak cenderung tumbuh lebih besar daripada anak yang kesehatan dan gizinya buruk. Anak yang diberi imunisasi terhadap penyakit selama awal masa kanak-kanak tumbuh lebih besar daripada anak yang tidak diberi imunisasi. Ketegangan emosional juga mempengaruhi pertumbuhan fisik. Anak yang mengalami gangguan emosional akan tumbuh lebih lambat daripada anak yang tenang. ${ }^{15}$

Berikutnya, anak juga mengalami perkembangan moral. Berdasarkan teori perkembangan moral L. Kohlberg, yang dikutip oleh Hurlock, anak usia 9-12 tahun berada pada tahap orientasi instrumental. Artinya, anak hanya mengharap dan mencari hadiah yang nyata. Perbuatan yang benar merupakan perbuatan yang hanya memuaskan kebutuhannya. Dengan kata lain, anak mengharapkan adanya hubungan timbal balik. ${ }^{16}$ Mereka semakin sadar akan tuntutan pihak yang ada di luar dirinya, seperti keluarga, sekolah, dan masyarakat. Kesadaran akan adanya orang lain dikonkretkan dalam loyalitas dan penyesuaian terhadap kelompok, keluarga, sekolah dan masyarakat. ${ }^{17}$

Di usia ini, menurut Kohlberg, anak mengalami dua bentuk perkembangan. Pada bentuk yang

${ }^{14}$ Elizabeth B. Hurlock, Psikologi Perkembangan: Suatu Pendekatan Sepanjang Rentang Kehidupan Edisi Kelima (Jakarta: Erlangga: 1980), 146-147.

${ }^{15}$ Ibid., 148.

${ }^{16}$ Ibid., 18. pertama, anak mengikuti peraturan untuk mengambil hati orang lain dan untuk mempertahankan hubungan-hubungan yang baik dengan kelompoknya. Pada bentuk yang kedua, Kohlberg mengatakan bahwa jika kelompok sosial membuat peraturan-peraturan yang sesuai bagi semua anggota kelompok, maka anak harus menyesuaikan diri dengan peraturan untuk menghindari penolakan kelompok dan celaan. ${ }^{18}$ Dengan kata lain, anak menunjukkan tanggung jawab dalam memelihara hukum dan peraturan tersebut supaya tidak mendapatkan hukuman dan dikucilkan dari kelompok.

Selain itu, anak juga mengalami perkembangan kognitif. Paul Suparno, yang mengutip pendapat Piaget dalam buku Teori Perkembangan Kognitif Jean Piaget, mengatakan bahwa anak usia 9-12 tahun termasuk dalam tahapan Operasional Konkret (7 atau 8 sampai 11 atau 12 tahun). ${ }^{19}$ Pada usia ini anak mulai dapat menggambarkan ingatan dan pengalamannya secara menyeluruh. Anak juga sudah dapat menggambarkan situasi sekolahnya, perjalanan dari sekolah ke rumahnya, dan sejenisnya. Selain itu, mereka tidak hanya memikirkan diri mereka sendiri, tetapi juga memikirkan orang lain. Walaupun demikian, pemikiran logisnya itu masih terbatas pada bendabenda konkret dan anak belum dapat memecahkan persoalan-persoalan abstrak. ${ }^{20}$

Menurut Singgih Gunarsa, masa anak usia 9-12 tahun ini ditandai dengan meningkatnya cara berpikir kritis. Anak tanggung suka menanyakan sebab dan akibat dengan cara menyanggah pendapat orang dewasa. Perkembangan anak berlangsung dengan cepat disertai

\footnotetext{
${ }^{17}$ Ibid., 162.

18 Ibid., 163.

${ }^{19}$ Paul Suparno, Teori Perkembangan Kognitif Jean Piaget (Yogyakarta: Kanisius, 2001), 68.

${ }^{20}$ Ibid., 69-87.
} 
motivasi yang kuat untuk mengembangkan pengetahuan dan berpetualang karena mereka merasa mampu. Mereka mulai belajar untuk mengambil tanggung jawab. $^{21}$

Berikutnya, anak juga mengalami perkembangan iman. Menurut James Fowler, usia 9-12 tahun berada dalam tahap iman eksistensial yang mistisharfiah. ${ }^{22}$ Iman mereka berkembang dengan cara menemukan pengalamanpengalaman pribadi. Cara utama untuk menemukan dan menilai pengalaman adalah melalui apa yang mereka alami secara pribadi dan mendengarkan cerita. Selain itu, iman mereka berkembang di dalam suatu kelompok di mana dia menjadi anggota dari kelompok tersebut. Di dalam kelompok tersebut, mereka memiliki pengalaman bersama. Selain itu, pada usia ini mereka hanya memahami simbol-simbol secara harfiah. ${ }^{23}$

Tidak dapat dipungkiri bahwa perkembangan iman sangat berkaitan dengan perkembangan moral. Perkembangan iman dan moral sangat tergantung kepada pola pendidikan di keluarga di mana anak itu dibesarkan. Sebagai contoh, anak tidak akan bersungguh-sungguh melakukan suatu peraturan bila tidak seluruh anggota keluarga itu melakukannya. Hal ini terjadi oleh karena pada diri anak terkandung keraguan akan kebenaran. Mereka juga meragukan bahwa suatu peraturan harus dipatuhi. ${ }^{24}$ Segala bentuk larangan yang keras tidak akan banyak bermanfaat bagi mereka. Akan tetapi, jika seseorang

\footnotetext{
${ }^{21}$ Singgih D. Gunarsa dan Yulia Singgih D. Gunarsa, Psikologi Praktis: Anak, Remaja dan Keluarga (Jakarta: BPK Gunung Mulia, 1995), 13. ${ }^{22}$ James W. Fowler, Stages of Faith: The Psychology of Human Development and the Quest for Meaning (San Fransisco: Harper \& Row, 1981), 131.

${ }^{23}$ Ibid.

${ }^{24}$ Agus Sujanto, Psikologi Perkembangan (Jakarta: Aksara Baru, 1985), 81-82.
}

memberikan larangan untuk melakukan sesuatu kepada anak, maka orang tersebut harus memberikan alternatif yang menggantikan larangan yang dikatakannya, sehingga si anak tidak menganggap larangan tersebut sebagai suatu tekanan. ${ }^{25}$

Dari pemaparan di atas, dapat dipahami perkembangan anak dalam usia 9-12 tahun, baik secara psikologis, sosial, fisik, moral, kognitif, maupun iman. Berbagai perkembangan tersebut perlu dipahami oleh para pendidik dalam rangka mendidik anak-anak. Melalui pengenalan yang baik tentang perkembangan anak didik, maka seorang guru dapat menyesuaikan materi pelajaran dan pendekatan-pendekatan pembelajaran yang tepat yang akan disuguhkan sesuai dengan tingkat kemampuan naradidik, sehingga hasil pembelajaran yang dicapai akan lebih optimal.

\section{c. Pendidikan Agama Kristen (PAK) Anak}

Horace Bushnell, dalam bukunya Christian Nurture, yang dikutip oleh Boehlke, mengatakan bahwa anak-anak dari keluarga Kristen sewajarnya bertumbuh dalam iman Kristen. 26 Pertumbuhan dalam iman Kristen itu mmbutuhkan proses pengajaran. Maka proses pengajaran mengenai agama dan nilai-nilai Kristiani perlu diberikan kepada seseorang mulai dari anak-anak. Kegiatan ini disebut sebagai Pendidikan Agama Kristen (PAK) Anak. Dengan demikian, PAK Anak dapat didefinisikan sebagai

25 Soerjono Soekanto, Anak dan Pola Perikelakuannya (Yogyakarta dan Jakarta: Kanisius dan BPK Gunung Mulia, 1985), 52.

26 Horace Bushnell, Christian Nurture (New Haven: Yale University, 1960), dikutip Robert R. Boehlke, Sejarah Perkembangan Pikiran dan Praktek Pendidikan Agama Kristen (Jakarta: BPK Gunung Mulia, 2005), 488. 
proses pengajaran agama dan nilai-nilai Kristiani yang diberikan kepada anak supaya anak bertumbuh di dalam iman Kristen.

Dari pemaparan di atas, sudah jelas bahwa PAK tidak hanya dibutuhkan oleh orang-orang dewasa. Justru PAK perlu ditanamkan sejak dini kepada anak sehingga anak bisa bertumbuh sesuai dengan nilai-nilai dan ajaran Kristus. PAK harus dilaksanakan sesuai dengan tingkat kecerdasan dan kebutuhan anak-anak, termasuk bagi anak-anak. Di lain pihak, secara khusus, Makoni, seorang sarjana yang meneliti kurikulum dari perspektif disabilitas menyebutkan bahwa PAK harus dilaksanakan sesuai dengan tingkat kecerdasan dan kebutuhan anak-anak dengan tantangan mental. ${ }^{27}$

PAK Anak akan menjadi dasar pertumbuhan rohani seorang anak untuk dapat mengenal kebenaran Alkitab, menyembah dan memuji Tuhan, serta mengasihi setiap pekerjaan-Nya. ${ }^{28}$ Oleh karena itu, Gereja tidak boleh meremehkan tugas panggilannya untuk memberikan PAK Anak yang berkualitas. Anak-anak tidak boleh dipinggirkan di Gereja. Yesus sendiri menerima anak-anak dan memberkati mereka. Alkitab menuliskan kata-kata Yesus, "Biarkan anak-anak itu datang kepada- $\mathrm{Ku}$, jangan menghalanghalangi mereka, sebab orang-orang yang seperti itulah yang empunya Kerajaan
Allah" (Mrk. 10:14, Mat. 19:14, Luk. 18:16). Penulis menyetujui pendapat Tabita Kartika Kristiani yang mengatakan, "Seperti Yesus menghargai dan menerima anak-anak, demikian pula seharusnya gereja menghargai dan menerima anak melalui PAK Anak."29

\section{Desain Kurikulum PAK Anak}

\section{a. Kurikulum PAK}

Secara akademis, menurut Wyckoff, kurikulum PAK adalah pengalaman yang dibimbing menuju kepada pemenuhan tujuan PAK yang meliputi tindakan dan usaha dalam menjalin relasi dengan sesama. ${ }^{30}$ Di lain pihak, Paulus Lilik Kristianto menyebutkan bahwa kurikulum PAK adalah mata pelajaran-mata pelajaran yang harus dipelajari para naradidik PAK. ${ }^{31}$ Kurikulum berarti materi pelajaran yang diatur sedemikian rupa untuk mengarahkan siswa secara teratur melalui instruksi dan disiplin. Ketika kata PAK ditambahkan di depan kata kurikulum, maka kurikulum tersebut memiliki kekhususan tersendiri. Oleh karena itu, menurut penulis, kurikulum PAK dapat didefinisikan sebagai rangkaian pelajaran yang diatur sedemikian rupa untuk mengarahkan naradidik secara sistematis melalui ajaran dan disiplin yang khas

konsep-dan-orientasi. Diakses pada tanggal $14 \mathrm{Mei}$ 2019, pukul 17:50 WIB.

${ }^{29}$ Tabita Kartika Christiani, Pendidikan Anak: Penting Tetapi Disepelekan? Dalam Ajarlah Mereka Melakukan, Andar Ismail (Jakarta: BPK Gunung Mulia, 2006), 56.

${ }^{30}$ D. Campbell Wyckoff, Theory and Design of Christian Education Curriculum (Philadelphia: The Westminster Press, 1960), 27.

${ }^{31}$ Paulus Lilik Kristianto, Prinsip \& Praktik Pendidikan Agama Kristen: Penuntun bagi Mahasiswa Teologi dan PAK, Pelayan Gereja, Guru Agama, dan Keluarga Kristen (Yogyakarta: ANDI, 2000), 38. 
agama Kristen yang menjadi dasar pembentukan diri seseorang.

Isi kurikulum PAK diarahkan pada pelajaran-pelajaran yang memungkinkan dapat dipelajari secara lebih baik. Misalnya, kurikulum PAK Gereja yang terbagi dalam dua pokok besar, yaitu:

- Iman Kristen, antara lain: doktrin tentang Allah Tritunggal, Malaikat dan Iblis, doktrin tentang Alkitab, masa depan dunia ditinjau dari sudut pandang Alkitab, doktrin tentang manusia, doktrin tentang dosa dan keselamatan.

- Praktik hidup orang Kristen, antara lain: doktrin tentang Gereja, mengasihi pelayanan dalam pekerjaan Tuhan, etika Kristen, doa dalam kehidupan orang Kristen, penginjilan sedunia. ${ }^{32}$

Tujuan dari kurikulum PAK adalah untuk mencapai proses belajar dan mengajar mencapai hasil sasaran yang jelas. Dengan mengetahui sasaran tertentu, berbagai kegiatan dan sarana akan diupayakan ada dan terlaksana. Tujuan yang ingin dicapai dapat mencakup tujuan jangka panjang, tujuan jangka menengah dan tujuan jangka pendek. Tujuan jangka panjang merupakan tujuan akhir yang akan dicapai. Untuk mencapainya harus melalui tujuan jangka pendek (tujuan yang segera akan dicapai) dan tujuan jangka menengah (tujuan antara). ${ }^{33}$

Dalam kurikulum PAK, peran Alkitab sangat penting. Bagaimanapun, elemen yang paling diyakini dapat menjadi fokus dan menjadi penuntun yang tidak dapat salah bagi PAK, baik dari sudut pandang teologi maupun sudut pandang pendidikan, adalah Alkitab. Kemudian, petunjuk yang paling menjanjikan agar teori PAK layak dan dapat

\footnotetext{
32 Ibid., 38.

33 Ibid., 37.

${ }^{34}$ D. Campbell Wyckoff, The Gospel and Christian Education (Philadelphia: The Westminster Press, 1959), 97-98.
}

dikomunikasikan adalah pengenalan dan penggunaan Alkitab itu sendiri. Alkitab memberikan prinsip-prinsip yang menuntun PAK karena mengandung kabar baik tentang tindakan penebusan Allah melalui Yesus Kristus. ${ }^{34}$

Wyckoff memberi lima argumen berikut ini untuk mendukung sarannya menggunakan Alkitab sebagai penuntun dasar bagi teori PAK, yaitu:

- Wahyu, Firman Allah, adalah pusat dalam teori PAK.

- Injil, tindakan penebusan Allah melalui Yesus Kristus, adalah jantung dari Firman yang telah disampaikanNya kepada manusia, dari sepanjang abad sampai kepada manusia masa kini.

- Injil adalah kunci untuk memaknai sejarah.

- Injil adalah kunci untuk memaknai pengalaman.

- Injil adalah alasan eksisnya gereja; Injil membawa gereja kepada eksistensi, Injil memelihara gereja; Injil memberi tahu, mengarahkan dan mengoreksi gereja. ${ }^{35}$

Di pihak lain, Sara Little dalam buku The Role of the Bible in Contemporary Christian Education mengatakan, kedalaman PAK sepanjang sejarah dan filosofi PAK yang sekarang muncul tampaknya berkaitan erat dengan berkembangnya minat terhadap Alkitab. Hal itu tampak dari pesan pengajarannya, otoritasnya dan relevansinya. ${ }^{36}$ Dalam PAK, pesan Alkitab disampaikan sesuai dengan pengalaman para anggota komunitas Kristen yang ditandai oleh kehadiran Roh Kudus. Hal ini berasal dari keyakinan bahwa Alkitab adalah Firman Allah bagi manusia, dan bahwa PAK harus

\footnotetext{
35 Ibid., 98.

36 Sara Little, The Role of the Bible in Contemporary Christian Education (Virginia: John Knox Press, 1962), 5.
} 
menjadi saluran yang semakin efektif untuk komunikasi Injil. ${ }^{37}$

\section{b. Desain Kurikulum PAK Anak}

Menurut KBBI, kata desain berarti kerangka bentuk, rancangan, motif, pola, atau corak. Istilah desain memiliki makna keseluruhan, struktur, kerangka atau outline, dan urutan atau sistematika kegiatan. ${ }^{38}$ Selain itu, kata desain juga memiliki arti sebagai proses perencanaan yang sistematik yang dilakukan sebelum tindakan pengembangan atau pelaksanaan sebuah kegiatan. ${ }^{39}$ Kemudian, kata mendesain berarti membuat desain, atau membuat rancangan pola dan sebagainya. ${ }^{40}$

Secara umum, desain kurikulum dapat diartikan sebagai rancangan proses dimana tujuan pendidikan dikaitkan dan diatur sedemikian rupa dengan pilihan dan isi pengajaran. Ada beberapa hal yang melandasi desain kurikulum, antara lain: tujuan pendidikan, sumber tujuan, karakteristik peserta didik, hakikat proses belajar, dan tipe masyarakat yang dilayani. 41 Terrance R. Carson menyebutkan bahwa sebuah desain kurikulum sebaiknya dipandang sebagai pembukaan kemungkinan yang memampukan terjadinya pembelajaran, bukan sebagai manajemen hasil yang diharapkan. Melalui desain kurikulum, ada banyak kemungkinan yang menjadi

${ }^{37}$ Ibid., 5-6.

${ }^{38}$ G.W. Gagnon dan M. Collay, Designing for Learning: Six Elements in Constructivist Classroom (California: Corwin Press. Inc, 2001) dalam Benny A. Pribadi, Model Desain Sistem Pembelajaran (Jakarta: Dian Rakyat, 2010), 58.

${ }^{39}$ P.L. Smith dan T.L. Ragan, Instructional Design: Upper Saddle River (NJ: Merril Prentice Hall, Inc., 1993), 4, dalam Benny A. Pribadi, Model Desain Sistem Pembelajaran (Jakarta: Dian Rakyat, 2010), 58.

40 Arti Kata Desain, https://kbbi.web.id/desain, diakses pada tanggal 12 Juni 2019, pukul 19:00 WIB. kesempatan untuk memampukan terjadinya pembelajaran. Oleh karena itu, desain kurikulum sebaiknya tidak sematamata dilihat sebatas usaha untuk mencapai hasil yang diharapkan, melainkan kesempatan yang terbuka lebar untuk terjadinya proses pembelajaran. ${ }^{42}$ Selanjutnya, terkait dengan pendidikan umum, S. Nasution mengatakan bahwa kurikulum sekolah perlu diatur sedemikian rupa, sehingga bakat murid mendapat kesempatan penuh untuk berkembang, malahan ada pula yang menganjurkan agar kurikulum bukan saja disesuaikan dengan bakat murid, melainkan didasarkan pada bakat tiap-tiap murid. ${ }^{43}$

Kurikulum PAK Anak perlu didesain sedemikian rupa didasarkan pada kebutuhan dan cara belajar dari anak-anak, dengan tujuan supaya mereka semakin mengenal kasih Allah dan mengalami perkembangan iman. Selain itu, kurikulum PAK Anak juga perlu didesain supaya program PAK Anak berjalan dengan efektif. Kurikulum PAK Anak tersebut perlu diatur dengan manajemen yang baik. Hal ini sesuai dengan pernyataan Dadang Suhardan bahwa manajemen kurikulum merupakan sebuah proses atau sistem pengelolaan yang dapat digunakan, meningkatkan pemahaman dan sistematis untuk mengacu ketercapaian tujuan kurikulum yang sudah dirumuskan. Proses manajemen kurikulum membutuhkan

\footnotetext{
${ }^{41}$ Anik Ghufron, Desain Kurikulum yang Relevan untuk Pendidikan Karakter, http://staffnew.uny. ac.id/upload/131782837/pendidikan/DESAIN+K URIKULUM.pdf, diakses pada tanggal 12 Juni 2019, pukul 17:40 WIB.

42 Terrance Carson, Beyond Curriculum Management. The ATA Magazine, (May/June 1989), 52-55, dalam William F. Pinar, William M. Reynolds, Patrick Slattery, dan Peter M. Taubman, Understanding Curriculum: An Introduction to the Study of Historical and Contemporary Curriculum Discourses (New York: Counterpoints, 2008), 684. ${ }^{43}$ S. Nasution, Asas-asas Kurikulum (Bandung: Jemmars, t.t.), 54.
} 
kerja sama oleh pihak-pihak yang terkait. Pelaksanaannya mengacu kepada tujuan kurikulum yang sudah ditentukan sebelumnya. ${ }^{44}$

\section{Teori Kurikulum Wyckoff}

\section{a. Kurikulum PAK menurut Wyckoff}

Menurut Wyckoff, kurikulum PAK adalah sebuah rencana di mana proses belajar-mengajar dapat dilakukan secara sistematis dalam komunitas Kristen, yang memerlukan delapan hal, yaitu: gagasan yang jelas tentang alasan pengajaran dan pembelajaran Kristen, gereja sebagai Tubuh Kristus, rumah yang kristiani, sekolah gereja, bahan pengajaran yang baik, perhatian pada dan untuk masyarakat, berbagai sarana dan prasarana yang mengundang anak-anak, pemuda, dan orang dewasa untuk menjelajah ke kehidupan Kristen, serta administrasi yang cerdas, terampil, dan terdidik. ${ }^{45}$

Bila kita mempersempit masalah kurikulum hanya sebatas masalah suatu materi pengajaran semata, hal itu mencerminkan sebuah pemahaman yang salah dalam proses pendidikan gereja. Wyckoff menyebutkan bahwa akan lebih baik untuk menentukan istilah kunci secara eksplisit. Menurut Wyckoff, kurikulum adalah pengalaman di bawah bimbingan menuju pemenuhan tujuan pendidikan Kristen. Pengalaman itu direncanakan dan diprogramkan secara sadar. Rencana dan program tersebut digunakan gereja untuk memenuhi kewajiban pendidikannya. Rencana itu terdiri prosedur pendidikan yang dipilih dan digunakan untuk membantu pelajar memahami, menerima, dan memenuhi

${ }^{44}$ Dadang Suhardan, dkk., Manajemen Pendidikan (Bandung: Alfabeta, 2009), 191.

${ }^{45}$ D. Campbell Wyckoff, Theory and Design of Christian Education Curriculum (Philadelphia: The Westminster Press, 1961), 26-27. tujuan penebusan Allah dalam Yesus Kristus. ${ }^{46}$

Kurikulum diaturkan secara ilmiah di dalam teori kurikulum. Teori kurikulum adalah prinsip-prinsip yang bertindak sebagai panduan yang baik untuk praktik kurikulum, yaitu: prinsip-prinsip yang berkenaan dengan orientasi, desain, dan penggunaan dan efisiensi kurikulum. ${ }^{47}$ Sementara itu, desain kurikulum merupakan penyusunan cetak biru untuk program pendidikan dalam prinsip-prinsip panduan belajar-mengajar yang baik. Desain kurikulum merupakan strategi untuk menuntun beragam aspek program. Desain kurikulum juga mencakup strategi penyediaan sarana untuk membantu proses pendidikan. ${ }^{48}$

Setelah mengetahui definisi kurikulum, teori kurikulum dan desain kurikulum, Wyckoff juga menjelaskan mengenai isi kurikulum dan bahan-bahan kurikulum. Menurut Wyckoff, isi (content) kurikulum meliputi ruang lingkup pendidikan Kristen, seluruh bidang hubungan dalam terang Injil, keprihatinan besar dari iman Kristen dan kehidupan Kristiani. Kemudian, bahan-bahan kurikulum atau materi kurikulum adalah sumber-sumber (yang dicetak dan lainnya) yang digunakan dalam membimbing atau menuntun pengalaman belajar-mengajar. ${ }^{49}$ Demikianlah pemaparan tentang teori kurikulum Wyckoff.

\section{b. Desain Kurikulum PAK menurut Wyckoff}

Kurikulum adalah rencana pembelajaran dimana proses belajarmengajar dapat dilakukan secara teratur dan berkesinambungan oleh gereja. Menurut Wyckoff, desain kurikulum

\footnotetext{
${ }^{46}$ Ibid., 27-28.

${ }^{47}$ Ibid.

${ }^{48}$ Ibid.

${ }^{49}$ Ibid.
} 
dilakukan menurut beberapa hal dasar, yaitu: konteks, ruang lingkup, tujuan, dan proses. Prinsip-prinsip tersebut akan memberikan panduan dasar mengenai di mana pendidikan dan kurikulumnya berlangsung, konten apa yang terlibat, tujuan mendasar yang memandu mereka, dan proses pengajaran. Selain itu, Wyckoff juga memaparkan tentang prinsip pengorganisasian kurikulum dan cara mengimplementasikannya. 50 Dengan demikian, beberapa langkah yang dapat dilakukan untuk mendesain kurikulum dipaparkan di bagian berikut ini.

\section{1) Mengidentifikasi Konteks Pengajaran $P A K$}

Konteks pengajaran PAK dalam kurikulum adalah tempat, situasi dan kondisi di mana pada proses PAK berlangsung. Menurut Wyckoff, konteks pengajaran PAK adalah setiap tempat, situasi dan kondisi di mana Alkitab diajarkan, di mana doktrin Kristen diajarkan, di mana kehidupan Kristen dihidupi, di mana ada masyarakat yang baik dan mendidik, atau di mana gereja menjalani hidupnya dan melakukan pekerjaannya. ${ }^{51}$ Dengan kata lain, konteks PAK adalah gereja, komunitas pengikut Kristus yang beribadah, bersaksi, dan melayani. ${ }^{52}$

\section{2) Menentukan Ruang Lingkup Pengajaran PAK.}

Istilah ruang lingkup PAK digunakan untuk menunjukkan isi kurikulum. Wyckoff membuat rumusan unsur-unsur ruang lingkup PAK sebagai berikut:

${ }^{50}$ D. Campbell Wyckoff, Theory and Design of Christian Education Curriculum (Philadelphia: The Westminster Press, 1961), 114.

${ }^{51}$ Ibid., 114.
- Allah (Bapa, Anak, dan Roh Kudus) datang kepada manusia di dalam Firman. Hal ini diberitahu melalui Alkitab dan dalam kehidupan gereja. Allah memanggil manusia ke dalam relasi yang hangat dengan-Nya.

- Manusia, supaya warga jemaat melihat dan berhubungan dengan sesama, manusia diciptakan (dalam gambar Allah), manusia jatuh ke dalam dosa, kemudian manusia ditebus dari dosa.

- Alam, sehingga warga jemaat melihat dan menghubungkan alam sebagai latar tempat Tuhan menciptakan manusia untuk hidup.

- Sejarah, sehingga warga jemaat melihat dan menghubungkan sejarah tersebut sebagai rangkaian kegiatan Tuhan dan kehidupan manusia. ${ }^{53}$

\section{3) Menetapkan Tujuan PAK}

Tujuan kurikulum menurut Wyckoff adalah adalah untuk membantu orang agar sadar akan pengungkapan diri Allah dan mencari cinta dalam Yesus Kristus dan untuk menanggapinya dalam iman dan cinta - sampai akhir sehingga mereka dapat mengetahui siapa mereka dan bagaimana keadaan manusia mereka tumbuh ketika anak-anak Allah berakar dalam komunitas Kristen, hidup dalam Roh Allah dalam setiap hubungan, memenuhi pemuridan umum di dunia, dan tinggal dalam harapan Kristen. ${ }^{54}$

Berarti, inti tujuan PAK adalah kesadaran akan wahyu dan Injil Allah. Melalui PAK Anak, setiap anak mengenali pengungkapan diri Allah dan menyadari bahwa mereka sudah menerima penebusan dosadalam kasih Yesus Kristus. Selanjutnya, kurikulum PAK Anak diarahkan supaya anak menanggapi

52 D. Campbell Wyckoff, The Objectives of Christian Education (Philadelphia: National Council of Churches, 1958), 18.

${ }^{53}$ Ibid., 125.

${ }^{54}$ Ibid., 129. 
pengungkapan diri Allah dan penebusan tersebut dalam iman dan kasih. Dengan demikian, dalam kurikulum PAK Anak ditetapkan tujuannya, yaitu untuk mengundang anak kepada kesadaran dan tanggapan akan pengungkapan dan penebusan dari Allah melalui Kristus. Tujuan gereja secara keseluruhan tentu perlu sejalan dengan tujuan PAK.

\section{4) Merancang Proses PAK}

Wyckoff menjelaskan bahwa pada dasarnya, proses pembelajaran melibatkan semua faktor yang berkaitan dengan masalah pengembangan kepribadian. Pengembangan kepribadian berlangsung dengan cara mendapatkan dan menyempurnakan pengalaman, serta menggunakan motivasi untuk melakukan sesuatu. Proses ini berlangsung sesuai dengan pola pertumbuhan dan perkembangan manusia, dan sangat dipengaruhi oleh budaya, masyarakat, dan kelompok-kelompok di mana seseorang menjadi anggota. ${ }^{55}$

Proses mengajar tidak lepas dari bimbingan untuk belajar. Dengan demikian, mengajarkan iman Kristen dan kehidupan Kristen berarti suatu proses mengundang orang ke dalam partisipasi yang berarti dalam kehidupan beribadah, bersaksi, dan melayani sesama dalam Kristus (menyiratkan aspek pribadi maupun kerjasama sebagai umat Allah). Ini adalah proses pendidikan Kristenpartisipasi yang dalam, keterlibatan, kehidupan dan kerja komunitas Kristiani. Secara terperinci, Wyckoff memaparkan berbagai proses PAK dalam kehidupan komunitas. Komunitas bagi pelaksanaan PAK ini terwujud dalam gereja. Bagi PAK, partisipasi dalam hidup dan karya komunitas iman menyiratkan partisipasi dalam kegiatan-kegiatan utama persekutuan.
- Komunitas mempelajari Alkitab

- Komunitas yang beribadah.

- Komunitas bertindak sebagai saksi, yang melakukan pengabdian dan aksi sosial.

- Komunitas mengekspresikan dirinya secara kreatif dalam ungkapan seni.

- Komunitas hidup sebagai persekutuan cinta kasih. ${ }^{56}$

Partisipasi dengan cara-cara seperti itu dalam kehidupan dan pekerjaan komunitas Kristen mendorong kebutuhan, mengajukan pertanyaan, menghadirkan masalah, dan mendorong minat.

Proses belajar membutuhkan tugas atau aktivitas. Tugas atau aktivitas itu dilakukan dengan melihat kaitannya dengan aktivitas Allah, guru, gereja, rumah dan lingkungan. Ini adalah proses yang kompleks dan membutuhkan komunikasi yang baik.

\section{5) Mengatur Pengorganisasian Kurikulum PAK.}

Berikut ini adalah prinsip pengorganisasian yang disarankan oleh Wyckoff: Kurikulum pendidikan Kristen dibuat dengan perencanaan untuk melibatkan peserta didik, dengan semua pengalaman pengembangan terorganisir yang beragam dari mereka, dalam studi yang sedang berlangsung di gereja, ibadah, aksi, ekspresi kreatif, persekutuan, dan penatalayanan, di mana mereka dibantu untuk bertatap muka dengan Injil melalui pembelajaran Alkitab, dan melalui pengabdian seumur hidup; melihat relevansi Injil dengan pemahaman tentang semua kehidupan - Allah, manusia, alam, dan sejarah, menerima janji dan implikasi dari iman Kristen, dan menjadi berkomitmen untuk keanggotaan dalam penyembahan, bersaksi, bekerja

${ }^{56}$ Ibid., 132. 
komunitas orang-orang dalam Kristus dan pemuridan penuh di dunia. ${ }^{57}$

Pernyataan prinsip pengorganisasian ini tergantung pada konsep bahwa pembelajaran terjadi melalui keterlibatan. Keterlibatan seperti itu, jika itu mengarah pada pembelajaran Kristen, secara tidak langsung menyiratkan pembelajar berpartisipasi dalam cara pribadi dalam kehidupan dan pekerjaan komunitas itu sendiri. Salah satu implikasi dari prinsip pengorganisasian ini adalah bahwa gereja pada kenyataannya harus menjadi kelompok sosial utama. Para anggotanya harus melakukan kegiatan nyata dan bergabung dalam misi gereja.

\section{6) Membuat Panduan Metode}

Kurikulum perlu memberikan panduan yang baik tentang pemilihan dan memilih metodologi yang paling tepat dalam terang prinsip-prinsip yang telah dikembangkan untuk mengatur proses pendidikan.

\section{7) Membuat Pedoman Kurikulum}

Selain itu, PAK juga membutuhkan pedoman atau panduan kurikulum. Panduan kurikulum akan menjadi bagian penting yang berhubungan dengan dasardasar perencanaan kurikulum, untuk digunakan pada tingkat interdenominasi, denominasi, regional, komunitas, dan jemaat lokal.

\section{8) Membuat Pedoman Pembelajaran}

Wyckoff mengatakan bahwa kurikulum memerlukan pedoman ataupun panduan pembelajaran. Pedoman pembelajaran adalah sumber ide dan kemungkinan, yang darinya dapat diambil ide dan kemungkinan yang lebih spesifik yang akan menjadi unit pembelajaran. Pedoman pembelajaran menawarkan

\footnotetext{
57 Ibid., 144.
}

${ }^{58}$ Ibid., 190. daftar saran, kegiatan, dan bahan yang komprehensif tentang suatu topik atau masalah yang berkaitan dengan hidup murid. Pedoman pembelajaran memungkinkan guru untuk membawa naradidik ke dalam proses pembelajaran. ${ }^{58}$

2) Membuat Pedoman Evaluasi

Panduan evaluasi, kriteria spesifik yang digunakan untuk menilai, dan prosedur untuk evaluasi akan berbeda untuk masing-masing bagian. Namun, tes mendasar dalam setiap kasus adalah, "Dalam hal apa aspek proses kurikulum ini berkontribusi, atau gagal berkontribusi, untuk pencapaian tujuan dasar pendidikan Kristen?" Kriteria untuk mengevaluasi setiap aspek dari kurikulum tidak boleh menyimpang jauh dari tujuan dasar pendidikan Kristen dan konsep konteks, ruang lingkup, dan proses yang begitu erat terkait dengannya. Lebih baik menggunakan hasil secara faktual sebagai deskripsi untuk diperiksa terhadap objek daripada menetapkannya secara kaku sebagai kriteria yang digunakan untuk menilai hasil pengajaran. ${ }^{59}$

\section{Metode Penelitian}

Dalam penyusunan penelitian ini, penulis menggunakan metode penelitian deskriptif kualitatif. Dalam proses penyusunan ini, penulis melakukan penelitian pustaka dan penelitian lapangan. Penelitian dilakukan di Sinode Gereja Kristen Protestan Simalungun (GKPS). Penulis melakukan wawancara di dua lokasi, di Kantor Sinode GKPS dan di salah satu jemaat lokal GKPS. Pertama, penulis mewawancarai kepengurusan tingkat sinodal yang berlokasi di Pematangsiantar. Wawancara tersebut dilakukan terhadap Pimpinan Pusat GKPS (Ephorus dan Sekretaris Jenderal), Kepala

${ }^{59}$ Ibid., 197. 
Departemen Pembinaan, Kepala Bidang Pembinaan Kategorial, Kepala Departemen Kesaksian, Kepala Departemen Pelayanan, di Kantor Pusat GKPS di Pematangsiantar mengenai keberadaan kurikulum PAK Anak di GKPS dan penyusunan buku Bahan Pembelajaran Seksi Sekolah Minggu GKPS Aku Gereja. Selain itu, penulis juga mewawancarai Pembimbing dan Pengurus Seksi Sekolah Minggu Tingkat Pusat. Penelitian ditujukan kepada kepengurusan tingkat sinodal tersebut karena mereka memiliki wewenang untuk mengkoordinasikan seluruh pelayanan dan program PAK di Gereja.

Kedua, penelitian lapangan dilakukan di salah satu jemaat GKPS. Dalam penelitian di jemaat ini, penulis melakukan wawancara kepada perwakilan pihak-pihak yang memiliki relasi dengan desain kurikulum PAK Anak: Guru Sekolah Minggu (GSM), Pembimbing dan Pengurus Sekolah Minggu (PSM), dan majelis jemaat (MJ). Penelitian diadakan di jemaat GKPS Cengkareng. Penelitian diadakan di jemaat GKPS Cengkareng karena SM GKPS Cengkareng memakai buku Bahan Pembelajaran Seksi Sekolah Minggu GKPS Aku Gereja dalam pengajaran Sekolah Minggu. Alasan lain merupakan alasan efisiensi waktu penelitian. Selain itu, penulis adalah anggota jemaat di Gereja tersebut dan berpartisipasi dalam tugas pelayanan di jemaat tersebut. Dengan demikian, penulis dapat melihat secara langsung dan mengetahui kebutuhan-kebutuhan maupun masalah-masalah nyata (real) yang dihadapi oleh Sekolah Minggu di jemaat tersebut.

Penulis melakukan wawancara untuk mengumpulkan data tentang pendapat-pendapat dan kritik-kritik

60 Sugiyono, Metode Penelitian Pendidikan (Bandung: Alfabeta, 2012), 96. terhadap buku Bahan Pembelajaran Seksi Sekolah Minggu GKPS Aku Gereja. Selain itu, penulis juga mengumpulkan masukanmasukan dan harapan-harapan mereka terhadap penyusunan kurikulum dan buku pedoman pembelajaran Anak Sekolah Minggu GKPS untuk tahun-tahun yang akan datang. Penelitian dilakukan dalam jangka waktu tertentu. Penelitian lapangan ini dilaksanakan mulai dari bulan April sampai bulan Juli 2019.

Dalam penelitian ini, penulis menentukan sampel yang ingin diwawancarai yaitu dengan menggunakan teknik sampel nonprobabilitas (sampel purposif). Teknik penentuan sampel ini disebut juga teknik sampel bertujuan, di mana seseorang dapat dijadikan sampel berdasarkan tujuan tertentu. ${ }^{60}$

Selain itu, sampel dalam penelitian ini dapat juga digolongkan sampel pertimbangan. Sampel pertimbangan adalah informan-informan atau narasumber-narasumber yang dipilih berdasarkan pertimbangan bahwa mereka dapat memenuhi tujuan studi sesuai dengan kemampuan dan pengalaman mereka. ${ }^{61}$ Dalam hal ini, penulis melakukan proses seleksi terhadap subyek penelitian (informan) yang menjadi sampel. Proses seleksi informan dilakukan berdasarkan beberapa kriteria yang ditentukan oleh peneliti, seperti soal status dan fungsi (jabatan gerejawi dan peran tertentu). ${ }^{62}$ Untuk menentukan sampel pertimbangan, peneliti terlebih dahulu mengetahui atau mengenal lingkungan penelitian. Berdasarkan pengetahuan itulah informan-informan dapat diseleksi.

Berdasarkan kriteria dan pertimbangan penentuan sampel di atas, penulis menetapkan narasumber dalam penelitian ini. Narasumber yang diwawancarai adalah Pimpinan Pusat GKPS sebagai

\footnotetext{
${ }^{61}$ John Mansford Prior, Meneliti Jemaat: Pedoman Riset Partisipatoris (Jakarta: Grasindo, 1997), 38. ${ }^{6}$ Ibid.
} 
pimpinan sinode (yakni Ephorus dan Sekretaris Jenderal), Kepala Departemen Pembinaan, Kepala Bidang Pembinaan Kategorial, Kepala Departemen Kesaksian, Kepala Departemen Pelayanan, Pembimbing Seksi SM Tingkat Pusat dan Ketua Seksi SM Tingkat Pusat (semua berjumlah delapan orang). Ephorus dan Sekretaris Jenderal GKPS menjadi narasumber karena mereka adalah pimpinan tertinggi di sinode GKPS, yang mengetahui keadaan GKPS secara menyeluruh, termasuk kurikulum PAK Anak yang digunakan di seluruh jemaat GKPS. Kepala Departemen Pembinaan menjadi narasumber karena beliau yang memimpin proses pengadaan buku Bahan Panduan Pembelajaran Anak Sekolah Minggu GKPS Aku Gereja setiap tahun. Kepala Bidang Pembinaan Kategorial menjadi narasumber karena beliau yang mengurus proses penyusunan buku Bahan Pembelajaran Seksi Sekolah Minggu GKPS Aku Gereja setiap tahun di bawah koordinasi Kepala Departemen Pembinaan GKPS. Kemudian, Pembimbing Seksi SM Tingkat Pusat, Ketua Seksi SM Tingkat Pusat, Kepala Departemen Kesaksian dan Kepala Departemen Pelayanan menjadi narasumber karena mereka juga menangani pelayanan kepada anak-anak khususnya PAK Anak secara sinodal di GKPS.

Berikutnya, narasumber yang diwawancara di jemaat GKPS Cengkareng adalah wakil-wakil dari pihak-pihak yang berhubungan dengan PAK Anak di GKPS Cengkareng, dengan kriteria mencakup: unsur Guru Sekolah Minggu (dua orang GSM yang memiliki jadwal mengajar kelas 9-12 tahun), unsur Pembimbing dan Pengurus Sekolah Minggu (pembimbing dan bendahara Seksi Sekolah Minggu GKPS Cengkareng), dan unsur Majelis Jemaat (dua orang penatua yang masih aktif). Semua berjumlah enam orang. Dua orang GSM yang memiliki jadwal mengajar kelas 9-12 tahun menjadi narasumber karena mereka memiliki pengalaman langsung mengajar PAK Anak kepada ASM usia 9-12 tahun. Pembimbing dan pengurus SM menjadi narasumber karena mereka yang mengelola pelayanan anak dalam lingkup jemaat berdasarkan kebutuhan ASM tersebut. Kemudian, dari unsur Majelis Jemaat dipilih dua orang penatua yang masih aktif dengan kriteria mereka memiliki wawasan yang luas mengenai anak dan pengalaman dalam mengajar SM.

Instrumen penelitian yang penulis gunakan adalah pedoman wawancara. Selanjutnya, penulis mengumpulkan data, melakukan analisis dan mengolah data yang sudah dikumpulkan. Wawancara dilaksanakan pada bulan Juni sampai Juli 2019. Responden di kepengurusan tingkat sinodal GKPS di Pematangsiantar, yaitu: Pimpinan Pusat GKPS sebagai pimpinan sinode (yakni Ephorus dan Sekretaris Jenderal), Kepala Departemen Pembinaan, Kepala Bidang Pembinaan Kategorial, Pembimbing Seksi SM Tingkat Pusat (sekaligus Kepala Departemen Persekutuan) dan Ketua Seksi SM Tingkat Pusat. Di lain pihak, orang-orang yang diwawancara di jemaat GKPS Cengkareng adalah: dua orang GSM yang memiliki jadwal mengajar anak usia 9-12 tahun, ketua dan sekretaris mewakili unsur Pengurus Sekolah Minggu (PSM), dan dua orang Majelis Jemaat (MJ) GKPS Cengkareng yang berpengalaman mengajar ASM.

\section{Hasil Penelitian dan Pembahasan}

\section{Gambaran Umum Sinode GKPS}

\section{a. Sejarah Singkat GKPS}

Sinode GKPS adalah salah satu sinode gereja suku Protestan di Indonesia. Karena bersifat sinodal, GKPS memiliki kantor sinode atau kantor pusat, yaitu di 
Pematangsiantar, Kabupaten Simalungun, Sumatera Utara. Sebagaimana sudah disinggung pada bab pertama, sejarah GKPS dimulai sejak sampainya Injil di Tanah Simalungun pada tanggal 2 September 1903 oleh August Theis (seorang misionaris dari Jerman) dan teman-temannya guru-guru zending dari Tapanuli. Setelah itu, dimulailah pekabaran Injil dan pelayanan di Simalungun di bawah naungan Huria Kristen Batak Protestan (HKBP). Seiring dengan perkembangan dan pertambahan warga jemaat, serta motivasi yang kuat untuk melestarikan budaya Simalungun, diresmikanlah Sinode GKPS pada tanggal 1 September 1963. Selanjutnya, sinode GKPS mengalami perkembangan dan penyebaran. ${ }^{63}$ Dalam proses pelayanan, terbentuklah beberapa seksi (pelayanan kategorial), yaitu, Seksi Pemuda (tanggal 26 Desember 1953), Seksi Wanita (Maret 1958), Seksi Sekolah Minggu (1968), dan Seksi Bapa (tanggal 8 April 1995). ${ }^{64}$

\section{b. Visi dan Misi GKPS}

Dalam pelayanannya, GKPS memiliki visi dan misi secara sinodal. Visi sinodal GKPS adalah "gabe Gareja siboan pasu-pasu janah sari tahun 2030", atau "menjadi Gereja pembawa berkat dan kepedulian tahun 2030". Untuk mencapai visi tersebut, ada beberapa misi yang dilakukan di GKPS. Misi GKPS tersebut adalah:

- Mengembangkan dan memperdalam spiritualitas yang berpusat kepada Allah.

- Melaksanakan persekutuan, kesaksian dan pelayanan secara benar berdasarkan Alkitab.

\footnotetext{
${ }^{63}$ Juandaha Raya Dasuha dan Martin Lukito Sinaga, "Tole! Den Timorlanden Das Evangelicum" (Pematangsiantar: Kolportase GKPS, 2003), 253.

64 Pimpinan Pusat GKPS, Susukkara 2019 (Pematangsiantar: Kolportase, 2019), 471-472.
}

- Membangun kesetiakawananan, kepedulian sosial dan ekonomi berbasiskan Injil.

- Meningkatkan kecintaan semangat gotong-royong di kalangan jemaat dan masyarakat (haroan bolon, sapangambei manoktok hitei).

- Menumbuhkembangkan cinta kasih kepada sesama dan keutuhan ciptaan. ${ }^{65}$

\section{c. Teologi GKPS}

Mengenai aspek teologis atau doktrinnya, GKPS banyak dipengaruhi pemahaman Lutheran. Teologi GKPS memiliki corak teologi Martin Luther. Teologi GKPS yang bersifat Lutheran tersebut menekankan keselamatan dan penebusan, dengan slogan-slogan Sola Gratia (keselamatan hanya karena anugerah), Sola Fide (keselamatan hanya karena iman), dan Sola Scriptura (keselamatan melalui ajaran Alkitab).

\section{d. Sistem Organisasi GKPS}

Sistem organisasi Gereja GKPS bersifat sinodal. Berdasarkan Tata Gereja dan Peraturan Rumah Tangga GKPS tahun 2013, pemimpin tertinggi di GKPS adalah Ephorus dan Sekretaris Jenderal, suatu jabatan yang bersifat dwitunggal. Persekutuan GKPS terwujud dalam jemaat-jemaat. Beberapa jemaat bersekutu dalam satu Resort. Beberapa resort bersekutu dalam Distrik. Seluruh jemaat bersekutu dalam GKPS. ${ }^{66}$

Sesuai ajaran Luther yang menganggap bahwa Firman dan Sakramen adalah pusat kehidupan Gereja, GKPS menganggap perlu adanya jabatan khusus yang ditahbiskan secara khusus, yakni

\footnotetext{
${ }^{65}$ Pimpinan Pusat GKPS, Visi dan Misi GKPS 2011-2030 (Pematang Siantar: Kolportase GKPS, 2013), xii.

66 Pimpinan Pusat GKPS, Tata Gereja dan Peraturan-peraturan GKPS (Pematangsiantar: Kolportase GKPS, 2013), 9.
} 
pemberita Firman dan pelayan Sakramen, dalam hal ini adalah Pendeta. Pendeta menjalankan tugas pengajaran dan penggembalaan di Gereja. Dalam pekabaran Injil dan pengajaran, di GKPS ada jabatan pelayanan Penginjil. Dalam menjalankan pelayanannya, Pendeta dan Penginjil dibantu oleh Penatua (sintua) dan Calon Penatua (syamas). Dalam pelayanan dan pengajaran anak, ada fungsi pelayanan dari Guru Sekolah Minggu.

Struktur organisasi GKPS terdiri dari Pimpinan Pusat, yaitu Ephorus dan Sekretaris Jenderal. Dalam pelayanannya, Pimpinan Pusat GKPS dibantu oleh beberapa kepala departemen dan kepala biro, antara lain: kepala departemen persekutuan, kepala departemen kesaksian, kepala departemen pelayanan, kepala departemen pembinaan, dan lainlain. ${ }^{67}$ Selain itu, setiap seksi kategorial memiliki kepengurusan di tingkat pusat, tingkat resort dan tingkat jemaat.

\section{Gambaran Umum GKPS Cengkareng}

\section{a. Sejarah Singkat GKPS Cengkareng}

Dari sejarah Gereja GKPS Cengkareng, diketahui bahwa pada awalnya Gereja ini dimulai dari orangorang Simalungun yang bertempat tinggal di Cengkareng (dan yang sudah saling mengenal). Akhirnya warga Simalungun yang sudah saling mengenal ini mempererat tali persaudaraan dengan membentuk satu wadah yang disebut dengan PSWS (Perkumpulan Sapanriahan Warga Simalungun). ${ }^{68}$ Setiap orang yang tergabung dalam organisasi ini sudah memiliki tempat ibadahnya masingmasing, di mana mayoritas tempat ibadahnya jauh dari lokasi tempat tinggal

67 Pimpinan Pusat GKPS, Susukkara 2019 (Pematangsiantar: Kolportase GKPS, 2019), 407.

${ }^{68}$ Sapanriah artinya kesepakatan bersama.

69 J.B. Sinaga, Benih yang Ditabur Sedang Bertumbuh: 25 Tahun GKPS Cengkareng, 6 masing-masing. Ada yang menjadi anggota GKPS Salemba, GKPS Cikoko, GKPS Cempaka Putih, GKI Seroja, dan lain-lain. Tempat ibadah yang jauh dari lokasi tempat tinggal tersebut, mendorong mereka untuk membentuk persekutuan Gereja dan membangun tempat ibadah yang lebih dapat terjangkau. Dengan alasan inilah akhirnya diadakan koordinasi serta kesepakatan bersama untuk mendirikan GKPS Cengkareng. Dengan kata lain, pembentukan dan pendirian Gereja ini didasarkan adanya kebutuhan pelayanan dan persekutuan yang mendesak, supaya perkembangan kerohanian jemaat juga tidak terbengkalai. Jumlah anggota juga sudah memadai untuk dijadikan jemaat. Dengan adanya kerja keras dari pengurus PSWS dan semangat anggota untuk memperjuangkan lahirnya GKPS Cengkareng, akhirnya niat tersebut direalisasikan. ${ }^{69}$

\section{b. Alamat dan Data Statistik Jemaat}

Dalam perkembangannya secara singkat, Gereja GKPS Cengkareng sekarang beralamat di Jl. Jati Raya RT 007/RW 12 No. 41, Kel. Cengkareng Timur, Jakarta. Dalam usia menjelang empat puluh dua tahun (ulang tahun Gereja terhitung dari tanggal berdiri Gereja GKPS Cengkareng, tanggal 6 November 1977), GKPS Cengkareng terdiri dari 125 keluarga tangga banggal (suami istri masih hidup), dan 27 keluarga tangga etek (salah satu, suami atau istri, sudah meninggal). Jumlah secara keseluruhan: 152 keluarga, 509 jiwa. Jumlah sintua (penatua): 32 orang. Jumlah syamas (calon penatua): 20 orang. $^{70}$

November 1977-2002 (Jakarta: GKPS Cengkareng, 2002), 8 .

70 Pimpinan Pusat GKPS, Susukkara 2019 (Pematang Siantar: Kolportase, 2019), 437. 


\section{c. Latar Belakang Kehidupan Jemaat}

Jemaat berasal dari latar belakang suku yang berbeda: Batak Simalungun, Batak Toba, Batak Karo, Jawa, Flores, Tionghoa, Ambon, dan lain-lain. Asal kampung halamannya juga berbeda-beda: ada yang berasal dari Simalungun Atas (daerah Silimakuta dan sekitarnya), dari Simalungun Tengah (daerah RayaPematangsiantar dan sekitarnya), dari Simalungun Bawah (daerah Raya Kahean dan sekitarnya), dari daerah danau Toba dan sekitarnya, dari Jakarta dan Jawa sekitarnya, dan lain-lain. Dari segi asal Gereja, warga jemaat tidak seluruhnya berasal dari Gereja GKPS. Banyak juga warga yang berasal dari luar GKPS. Ada yang berasal dari Katolik, dari berbagai aliran Protestan, seperti Calvinis, Reformed, Presbiterian, Karismatik, Pentakosta, dan lain-lain. Ada pula yang berasal dari umat Islam. Pada umumnya mereka masuk ke GKPS karena menikah dengan warga GKPS.

Kemajemukan dari segi pendidikan, warga jemaat ada yang berpendidikan Play-Group sampai pada yang sudah bergelar master (S2). Kemajemukan dari segi pekerjaan: wiraswasta, PNS, karyawan swasta, guru, ibu rumah tangga, pensiunan, tukang sayur/pedagang, supir, polisi, dokter, perawat, dan lain-lain.

Kemajemukan yang nyata lainnya adalah bahwa jemaat GKPS Cengkareng hidup bersama dengan lingkungan agama lain. Secara posisi/letak Gereja, GKPS Cengkareng berada di lingkungan umat beragama Islam. Gereja bertetangga dengan lingkungan Muslim. Di sekitar Gereja, ada beberapa Masjid. Selain itu, ada gedung sekolah negeri (SMA Negeri 96) di samping Gereja.

Secara organisasi, GKPS Cengkareng dipimpin oleh Pimpinan Majelis Jemaat, yang terdiri dari: ketua, wakil ketua, sekretaris dan bendahara.
Sementara seksi Sekolah Minggu GKPS Cengkareng dipimpin oleh pengurus Seksi Sekolah Minggu Jemaat, yang terdiri dari: ketua, wakil ketua, sekretaris, wakil sekretaris, bendahara, dan dua orang anggota, dibawah bimbingan seorang pembimbing. Pengurus juga dilengkapi dengan seorang kepala sekolah yang dipilih dari guru Sekolah Minggu.

Jadwal Kegiatan/Pelayanan:

Kegiatan PAK Anak di GKPS Cengkareng disebut Sekolah Minggu GKPS. Kegiatan ini dilangsungkan setiap hari Minggu pagi pukul 08.00-09.30. Kegiatan pembelajaran dilakukan di Gedung Sekolah Minggu GKPS Cengkareng.

\section{Deskripsi Data Penelitian}

\section{a. Data Wawancara terhadap Kepengurusan Tingkat Sinodal GKPS}

Penulis melakukan wawancara terhadap kepengurusan tingkat sinodal GKPS, mulai dari Ephorus, Sekretaris Jenderal, Kepala Departemen Pembinaan, Kepala Bidang Pembinaan Kategorial, Pembimbing Seksi SM Tingkat Pusat (sekaligus Kepala Departemen Persekutuan), Kepala Departemen Kesaksian, Kepala Departemen Pelayanan dan Ketua Seksi SM Tingkat Pusat. Jumlah keseluruhan responden di kepengurusan tingkat sinodal ini adalah delapan orang. Para responden diwawancara sebab penulis ingin mengetahui informasi, masukan dan harapan dari Pimpinan Pusat GKPS bersama jajaran kepengurusan tingkat sinodal GKPS sebagai pihak yang menyusun dan mengelola pelayanan GKPS di tingkat sinode. Berikut ini adalah penjabaran deskripsi data wawancara terhadap kepengurusan tingkat sinodal GKPS. 


\section{1) Pendidikan Agama Kristen (PAK) Anak}

Dalam mengumpulkan informasi mengenai hakikat PAK Anak, peneliti melakukan wawancara mengenai tiga hal, yaitu: pemahaman tentang PAK, pemahaman tentang anak dan pemahaman tentang PAK Anak. Mengenai bagian pemahaman tentang PAK, sebagian responden menjawab bahwa PAK adalah pengajaran kekristenan, sebagian lagi menjawab bahwa PAK adalah pengajaran Alkitab. PAK itu penting sekali untuk diberikan dan dilaksanakan di Gereja. Salah satu responden menyatakan bahwa GKPS sejak awal sebenarnya sudah sadar bahwa pengajaran Kristen itu dapat ditanamkan kepada warga jemaat melalui PAK. Akan tetapi, karena kurangnya SDM untuk menciptakan kurikulum PAK di GKPS, kurikulum maupun modul-modul tentang PAK nyaris tidak berkembang di GKPS. Secara umum, faktanya di lapangan jemaat-jemaat lebih banyak memperhatikan hal-hal fisik, tetapi kurang memperhatikan PAK. ${ }^{71}$

Mengenai pemahaman tentang Anak Sekolah Minggu, sesuai renstra GKPS 2016-2020, anak adalah warga GKPS dari usia 0 sampai 11 tahun. Pembagian kelas ada kelas kecil dan kelas besar. Kelas remaja memiliki seksi khusus. Namun secara pribadi, MRP berpendapat bahwa kelas remaja masih cenderung masuk dalam naungan seksi Sekolah Minggu. ${ }^{72}$ Selain itu, responden lainnya pada umumnya menjawab bahwa kategori anak itu dimulai dari anak yang baru lahir sampai anak itu angkat sidi. Pembagian kelas diatur dan ditentukan oleh Departemen Persekutuan. Pembagian kelasnya sesuai dengan tata ibadah yang di

71 Hasil wawancara dengan MRP, Pematang Siantar, 25 Juli 2019.

${ }^{72}$ Ibid.

${ }^{73}$ Hasil wawancara dengan ASP Pematang Siantar, 24 Juli 2019.
Agenda, ada ibadah untuk kelas kecil, kelas madya/tanggung dan remaja. Kelas Kecil: TK-Kelas 4 SD (umur 5-10 tahun). Kelas Madya/Tanggung: Kelas 5 SDKelas 2 SMP (umur 11-14 tahun). Kelas Remaja: umur 15 tahun sampai angkat sidi. ${ }^{73}$ Anak usia 9-12 tahun berada pada masa akhir golden age (tahun-tahun keemasan anak). Ketika seorang anak lahir dalam sebuah keluarga, masa 10 tahun pertamanya adalah masa-masa yang penting untuk menanamkan hal-hal penting bagi anak. Jadi Gereja semestinya berperan di situ. Gereja harus berkontribusi memperlengkapi kerohanian anak-anak itu. ${ }^{74}$ Mereka juga butuh waktu untuk sendiri, butuh untuk dihargai, dan diakui bahwa dia bukan lagi anak-anak. ${ }^{75}$

Mengenai pemahaman tentang PAK Anak, responden pada umumnya menjawab bahwa PAK Anak adalah pengajaran kekristenan dan tentang gereja untuk anak-anak, yang bertujuan supaya anak memahami kekristenan dan gereja. Responden mengatakan bahwa pada umumnya PAK Anak di Jemaat-jemaat dilaksanakan oleh GSM yang dipilih hanya karena suka kepada anak-anak, bukan karena memiliki fokus kepada PAK Anak. Ditemukan pula bahwa ada kesenjangan PAK Anak di jemaat GKPS di kota dan di desa. ${ }^{76}$

\section{2) Desain Kurikulum PAK Anak}

Desain kurikulum PAK dipahami responden sebagai rangkaian ajaran agama Kristen yang mau diajarkan. Tujuannya supaya naradidik memahami apa yang perlu dicapai untuk diajarkan. Sebagian lagi menjawab kurikulum PAK adalah pedoman atau tuntunan pengajaran PAK yang akan membawa kita pada tahapan

\footnotetext{
${ }^{74}$ Hasil wawancara dengan MRP.

${ }^{75}$ Hasil wawancara dengan TPS, Pematang Siantar, 23 Juli 2019.

${ }^{76}$ Hasil wawancara dengan JSP, Pematang Siantar, 22 Juli 2019.
} 
pengetahuan melalui pengajaran Alkitab yang sistematis dan kronologis. Tujuan supaya mengetahui apa yang perlu dicapai untuk diajarkan.

Semua responden menjawab bahwa belum ada kurikulum PAK Anak di GKPS. MRP secara personal memandang bahwa GKPS belum bisa mendesain kurikulum karena belum ada ahli PAK di kantor sinode GKPS. Ahli PAK yang dimiliki GKPS dibutuhkan menjadi dosen di sekolah teologi. ${ }^{77}$ Sebelumnya sudah pernah dicoba untuk menyusun kurikulum PAK Anak di GKPS. Tetapi kurikulum itu tidak ditindaklanjuti. Penyebabnya GKPS memiliki kesepakatan bersama dengan Gereja-gereja anggota Sekretariat Bersama United Evangelical Mission (Sekber UEM) tentang hal-hal yang terkait dengan teks khotbah. Rencana kurikulum itu terbentur dengan teks Alkitab, tema dan tujuan yang sudah ditentukan oleh Sekber UEM. ${ }^{78}$ Selanjutnya, responden berharap kurikulum PAK Anak dapat disusun sesuai dengan kebutuhan dan perkembangan anak usia 9-12 tahun. Perlu tahapan yang jelas untuk dicapai dalam kurikulum tersebut, agar setelah itu, anak siap untuk katekisasi sidi. Seluruh responden berpendapat bahwa Buku Bahan Pembelajaran Seksi Sekolah Minggu GKPS Aku Gereja yang dipakai selama ini belum dapat dikategorikan sebagai kurikulum PAK Anak. Buku itu hanya sebagai buku pegangan bagi guru saja. Buku tersebut perlu diperlengkapi dengan kurikulum yang sistematis dan kronologis.

1) Desain Kurikulum berdasarkan Teori Wyckoff

Mengenai teori Wyckoff ini, ada lima hal yang ditanyakan kepada responden. Pertanyaan-pertanyaan

\footnotetext{
${ }^{77}$ Hasil wawancara dengan MRP.

${ }^{78}$ Hasil wawancara dengan RJS, Pematang Siantar, 22 Juli 2019.

${ }^{79}$ Hasil wawancara dengan ASP.
}

tersebut mencakup pemahaman tentang konteks, ruang lingkup, tujuan, proses dan pengorganisasiannya. Menurut responden, konteks GKPS adalah kehidupan yang majemuk, sehingga anak perlu diajarkan supaya inklusif dan egaliter (membela kesetaraan). Selain itu, GKPS menghadapi tantangan kemajuan teknologi. Anak usia 9-12 tahun butuh rangkaian pengajaran yang melekat, dengan bahasa yang sederhana. Anak-anak GKPS hidup di tengah-tengah konteks keluarga dengan basis budaya yang menghadapi era serba digital. $^{79}$

Kemudian ruang lingkup dalam desain kurikulum PAK Anak Usia 9-12 tahun di GKPS adalah tema-tema yang universal dan parsial. Tema yang universal adalah pengakuan iman, dan sebagainya. Tema yang parsial adalah tema-tema yang terkait dengan budaya. ${ }^{80}$ Responden lain mengatakan bahwa ruang lingkup PAK anak itu mencakup tema-tema kemajuan teknologi, selain tentunya siapa itu Allah, Yesus, Roh Kudus, dan Gereja.

Kemudian, diusulkan tujuan pembelajaran supaya anak pada usia 9-12 tahun sudah mempunyai pemahaman yang teguh tentang iman yang inklusif dan egaliter. Selain itu, anak juga memahami budaya Simalungun. 81 Tujuan pembelajaran supaya anak punya pegangan yang kuat tentang iman, supaya anak mencintai Tuhannya, selanjutnya anak akhirnya mencintai komunitasnya dan gerejanya. ${ }^{82}$

Selanjutnya, mengenai proses, ada berbagai masukan menyangkut metodemetode dan cara pembelajaran yang efektif untuk dimasukkan dalam desain kurikulum PAK Anak Usia 9-12 tahun di GKPS. Proses belajar adalah bimbingan sehingga PAK Anak perlu melibatkan

\footnotetext{
${ }^{80}$ Hasil wawancara dengan MRP.

${ }^{81}$ Ibid.

${ }^{82}$ Hasil wawancara dengan PUM, Pematang Siantar, 22 Juli 2019.
} 
banyak orang, terutama orangtua. Metodenya adalah dengan memberikan anak pekerjaan rumah (PR) yang dikerjakan bersama oleh anak dan orangtua. Metode lain yang disarankannya adalah mengajar dengan membawa anak langsung bersentuhan dengan alam dan mengajarkan anak dengan mempraktekkannya secara langsung. Contohnya, untuk belajar tentang kasih, anak dapat diajak langsung ke panti jompo, panti asuhan, dan lain sebagainya. ${ }^{83}$ Proses pengajaran PAK Anak perlu kreativitas. Dalam pengajaran tersebut dibutuhkan alat peraga untuk memudahkan anak memahami materi yang diajarkan. Alat peraga yang dibuat pun tidak harus mahal, tetapi GSM dapat dengan kreatif membuatnya dari bahanbahan yang ada dan tersedia di sekitar mereka. Pengajaran PAK Anak juga perlu untuk dilengkapi dengan nyanyian rohani Simalungun. ${ }^{84}$

Kemudian, pembahasan mengenai pemahaman tentang pengorganisasian PAK anak, ada satu pertanyaan, mengenai pengaturan setiap unsur konteks, ruang lingkup, tujuan, dan proses PAK dalam desain kurikulum PAK Anak Usia 9-12 tahun di GKPS. Namun, ada beberapa jawaban yang berbeda-beda dari responden. MRP mengatakan bahwa untuk ibadah anak, sudah ada ayat-ayat yang ditetapkan dari Sekber UEM. Tetapi bahan tersebut perlu kembali diolah oleh GKPS sesuai dengan konteks GKPS. Misalnya di GKPS ada hari-hari khusus seperti pesta peringatan sampainya Firman Tuhan di tanah Simalungun (pesta olob-olob), bahan dari Sekber UEM tersebut wajib disesuaikan dengan perayaan tersebut. Selain itu, dalam penyusunan kurikulum PAK Anak, pengurus Litbang GKPS perlu dilibatkan untuk melakukan pengkajian

\footnotetext{
${ }^{83}$ Hasil wawancara dengan ASP.

${ }^{84}$ Hasil wawancara dengan JSP.

${ }^{85}$ Hasil wawancara dengan MRP.
}

khusus sehubungan dengan penyusunan kurikulum tersebut. ${ }^{85}$

\section{b. Data Wawancara terhadap Guru Sekolah Minggu, Pembimbing dan Pengurus Sekolah Minggu dan Majelis Jemaat GKPS Cengkareng}

Selain kepengurusan tingkat sinode, penulis juga melakukan penelitian terhadap kepengurusan Sekolah Minggu di sebuah jemaat lokal, GKPS Cengkareng. Tujuannya adalah untuk mendapatkan informasi, masukan dan harapan mereka yang secara langsung berhubungan dengan ASM, dan selanjutnya kepengurusan tingkat sinode juga mengetahui kendala dan harapan tersebut.

Berikut ini adalah penjabaran deskripsi data wawancara terhadap Guru Sekolah Minggu, pembimbing dan pengurus Sekolah Minggu, dan Majelis Jemaat GKPS Cengkareng, yang berjumlah enam orang.

\section{1) Pendidikan Agama Kristen (PAK) Anak}

Sebagian responden mengatakan bahwa PAK adalah pengajaran Alkitab. Sebagian lagi mengatakan PAK adalah pengajaran kekristenan. Kedua, pertanyaan tentang sejauh mana PAK itu penting di Gereja dijawab dengan jawaban yang mutlak. Semua menjawab bahwa PAK itu penting sekali di Gereja. Salah satu responden mengatakan bahwa PAK itu sangat penting, karena itu adalah filosofi kehidupan. PAK adalah kebutuhan dasar manusia atau Gereja. ${ }^{86}$ PAK bertujuan untuk membangun pondasi kekristenan dalam diri warga jemaat. Namun, dari pengamatan responden, pelaksanaan PAK di Gereja sebatas PA

\footnotetext{
${ }^{86}$ Hasil wawancara dengan JBS, Jakarta, 27 Juli 2019.
} 
dan khotbah.

Selanjutnya, mengenai pemahaman tentang Anak Sekolah Minggu, menurut responden, kategori anak itu dari anak yang baru lahir sampai anak itu angkat sidi. Pembagian kelas Sekolah Minggu di GKPS Cengkareng, anak dibagi dalam Kelas Anak kecil 1 (0TK), Kelas Anak Kecil 2 (Kelas 1-3), Kelas Anak Tanggung (Kelas 4-6), dan Kelas Besar (SMP ke atas). Untuk anak usia 9-12 tahun, anak sudah mulai tidak suka untuk bernyanyi, mulai membangkang, dan mulai malas untuk disuruh orangtua. Anak usia ini masih mencari jati diri. Jika mereka tidak diperhatikan dengan baik, mereka dapat menjadi rusak. Anak usia tersebut membutuhkan pengajaran yang baik. Mereka perlu "makanan pokok", bukan hanya diberi "jajan". Selain itu, mereka juga membutuhkan idola atau figur tertentu untuk dijadikan teladan.

Selanjutnya, PAK Anak dipahami sebagai pengajaran tentang iman dan kekristenan kepada anak-anak. PAK Anak bertujuan supaya anak semakin mengenal Yesus Kristus, sehingga mereka menjadi orang Kristen bukan hanya karena faktor keturunan, melainkan karena benar-benar percaya kepada Yesus Kristus. Seluruh responden mengatakan bahwa PAK Anak bagi usia 9-12 tahun itu sangat penting karena sesuai dengan perkembangan dan kebutuhan iman mereka, mereka harus benar-benar diberi pondasi iman kekristenan yang kuat. Kalau tidak, mereka bisa jatuh dalam dosa, seperti: berjudi, bolos, merokok, mabuk, narkoba, seks bebas, dan lain-lain.

\section{2) Desain Kurikulum PAK Anak}

Kurikulum dipahami sebagai panduan besar untuk mengembangkan

\footnotetext{
${ }^{87}$ Ibid.
}

pembelajaran (ada visi-misi, metode mengajar, dan bahan-bahan materi pengajaran). Semua responden menjawab bahwa belum ada kurikulum PAK Anak di GKPS. Mereka mengatakan kurikulum itu perlu untuk dibuat supaya ada tujuan yang jelas. Kurikulum itu seharusnya menjadi "makanan pokok" dalam PAK Anak. Buku Bahan Pembelajaran Seksi Sekolah Minggu GKPS Aku Gereja, belum dapat dikategorikan sebagai kurikulum PAK Anak. Buku itu hanya sebagai buku pegangan bagi guru saja. JBS dengan lebih tegas mengatakan bahwa buku tersebut hanya "jajanan" saja, bukan "makanan pokok" atau kurikulum. Buku itu sangat baik untuk diperlengkapi dengan kurikulum sesuai dengan tumbuh kembang anak. ${ }^{87}$

\section{3) Desain Kurikulum berdasarkan Teori Wyckoff}

Mengenai teori Wyckoff ini, ada lima hal pemahaman yang ditanyakan kepada responden. Pertanyaan-pertanyaan tersebut mencakup pemahaman tentang konteks, ruang lingkup, tujuan, proses dan pengorganisasiannya. Responden mengatakan konteksnya adalah kemajuan teknologi, anak-anak terbiasa bermain dengan gadget, ASM tidak lagi memahami bahasa Simalungun, sementara GKPS ingin melestarikan bahasa dan budaya Simalungun. ${ }^{88}$ Ruang lingkup PAK sangat luas, meliputi etika, sikap, cerita-cerita Alkitab, tentang organisasi Gereja di GKPS, lingkungan keluarga, karakter tokoh-tokoh Alkitab, sejarah (contohnya sejarah Israel keluar dari Mesir) dikaitkan dengan mempelajari peta Alkitab, tentang spiritualitas dan lain-lain. Tujuan dalam kurikulum PAK anak usia 9-12 tahun adalah supaya anak pada usia 9-12 tahun sudah mempunyai iman yang kuat,

${ }^{88}$ Hasil wawancara dengan JS, Jakarta, 29 Juli 2019. 
meningkatkan kemampuan anak baik kognitif (pengetahuan bertambah), afektif (timbul kepekaan), psikomotorik yang kuat (perubahan tingkah laku), untuk memenuhi kebutuhan anak, meningkatkan spiritualitas anak dan mempersiapkan anak menjadi manten Kristus. ${ }^{89}$

Selanjutnya, mengenai proses, responden mengusulkan supaya GSM mengajar dengan santai, berbeda dengan cara mengajar di Sekolah. Metode yang dapat digunakan antara lain diskusi kelompok, tanya-jawab, presentasi dan drama.

Kemudian, pengorganisasian setiap unsur konteks, ruang lingkup, tujuan, dan proses PAK dalam desain kurikulum PAK Anak Usia 9-12 tahun di GKPS perlu dirangkum dalam kurikulum. Kurikulum harus disusun dengan batasan usia tertentu dengan jangka waktu tertentu.

4. Analisis Data

\section{a. PAK Anak dan Ketidakkonsistenan Pembagian Kelas Sekolah Minggu}

Dari hasil wawancara kepada pihak-pihak yang terkait dengan PAK Anak di kepengurusan tingkat sinode GKPS, diperoleh gambaran bahwa PAK Anak adalah pembelajaran tentang nilainilai kekristenan dan Alkitab, gereja dan kehidupan untuk anak-anak. Seluruh responden menganggap bahwa PAK Anak sangat penting. Responden juga menekankan pentingnya PAK Anak karena PAK Anak bertujuan supaya anak mengetahui ajaran dari Alkitab dan kekristenan serta melakukan Firman Tuhan.

Dari hasil wawancara kepada GSM, PSM dan MJ di jemaat GKPS Cengkareng, diperoleh gambaran bahwa
PAK Anak adalah pengajaran tentang kekristenan dan Alkitab kepada anakanak. Seluruh responden menganggap PAK Anak sangat penting. PAK Anak bertujuan supaya anak mengetahui ajaran dari Alkitab untuk membangun pondasi kekristenan dalam diri anak sehingga anak itu memiliki identitas yang jelas bahwa dia itu orang Kristen.

Mengenai kategorisasi anak dan pembagian kelas Sekolah Minggu di GKPS, ditemukan adanya ketidakkonsistenan. Menurut rencana dan strategi (renstra) GKPS 2016-2020, anak adalah warga GKPS dari usia 0 sampai 11 tahun. Pembagian kelas terdiri dari kelas kecil dan kelas besar. Sementara kelas remaja memiliki seksi khusus di luar Seksi SM. ${ }^{90}$ Di pihak lain, menurut Agenda (Buku Tata Ibadah GKPS), pembagian kelas SM diatur dan ditentukan oleh Departemen Persekutuan. Pembagian kelasnya sesuai dengan tata ibadah anak yang ada di Buku Agenda, ada ibadah untuk ASM kelas kecil, kelas madya/tanggung dan remaja. Kelas Kecil adalah anak TK-kelas 4 SD (umur 5-10 tahun). Kelas Madya/Tanggung adalah anak kelas 5 SDkelas 2 SMP (umur 11-14 tahun). Kelas Remaja adalah anak umur 15 tahun sampai angkat sidi. ${ }^{91}$ Artinya ada perbedaan antara pembagian kelas dalam buku Agenda GKPS dengan renstra GKPS 2016-2020. Hal ini berpengaruh pada pembagian kelas anak di tiap-tiap jemaat. Akibat peraturan dari sinode tidak konsisten, pembagian kelas Sekolah Minggu di tiap-tiap jemaat tidak sama. Sebagai contoh, jemaat GKPS Cengkareng memahami kategori SM itu dari anak yang baru lahir sampai angkat sidi. Pembagian kelas SM di GKPS Cengkareng, anak dibagi dalam Kelas Anak Kecil 1 (0-TK), Kelas Anak Kecil 2 (Kelas 1-3), Kelas

${ }^{91}$ Hasil wawancara dengan ASP.

\footnotetext{
${ }^{89}$ Hasil wawancara dengan JBS.

${ }^{90}$ Hasil wawancara dengan MRP.
} 
Anak Tanggung (Kelas 4-6), dan Kelas Besar (SMP ke atas).

Adanya ketidakkonsistenan peraturan pembagian kelas Sekolah Minggu ini, menurut penulis, terjadi karena belum adanya SDM yang menangani PAK Anak secara khusus yang ditugaskan dalam kepengurusan tingkat sinodal. Pembagian kelas dilakukan tanpa ada konsep yang jelas tentang anak dan perkembangan anak. Hal ini mengakibatkan perbedaan pembagian kelas Sekolah Minggu dalam buku Agenda GKPS dan dalam renstra GKPS 20162020 yang sama-sama masih dipakai sampai saat ini.

$$
\text { Bila dibandingkan dengan }
$$
pemikiran dari pakar PAK, Ruth Kadarmanto mengatakan pembagian kelas Sekolah Minggu perlu dilakukan berdasarkan kebutuhan dan perkembangan anak. Dari pengalaman dan penelitiannya dalam PAK Anak, anak-anak Sekolah Minggu dapat dibagi antara lain berdasarkan usia tertentu. Ia membagi kelas Sekolah Minggu dalam kelompok: usia 3-5 tahun (usia taman bermain dan taman kanak-kanak), usia 6-8 tahun (kelas kecil, kelas 1-3 SD), usia 9-12 tahun (kelas besar, kelas 4-6 SD). Selanjutnya, usia 13 tahun ke atas sudah termasuk pra-remaja. ${ }^{92}$ Menurut penulis, pembagian kelas yang disampaikan oleh Kadarmanto lebih relevan untuk digunakan di Sekolah Minggu GKPS, karena sesuai dengan jenjang kelas dalam pendidikan sekuler. Menurut penulis, pembagian kelas di GKPS perlu disesuaikan dengan jenjang kelas pendidikan di sekolah biasa, supaya anak dan guru Sekolah Minggu lebih mudah menyesuaikan diri.

\footnotetext{
92 Ruth S. Kadarmanto, Tuntunlah ke Jalan yang Benar: Panduan Mengajar Anak di Jemaat (Jakarta: BPK Gunung Mulia, 2012), 42, 46, 50.
}

\section{b. Desain Kurikulum PAK Anak di Sinode GKPS Terkendala}

Menurut hasil wawancara, pada periode 2010-2015 sudah pernah dicoba untuk menyusun kurikulum PAK Anak di GKPS. Tetapi kurikulum itu tidak ditindaklanjuti. Penyebabnya GKPS memiliki kesepakatan bersama dengan Gereja-gereja anggota Sekretariat Bersama United Evangelical Mission (Sekber UEM) tentang hal-hal yang terkait dengan teks khotbah. Sekber UEM adalah bentuk kerjasama Gereja-gereja yang bersifat ekumenis. Bentuk kerja sama ditunjukkan dengan bersama-sama menentukan teks-teks Alkitab yang akan disampaikan (dalam khotbah maupun dalam bacaan/epistel) ke tiap-tiap jemaat. Oleh karena itu, GKPS menggunakan nas Alkitab, tema dan tujuan yang sudah ditetapkan oleh Gereja-gereja anggota Sekber UEM.

Ketika masalah ini dikonfirmasi kepada Pimpinan Pusat GKPS, semakin terlihat akar masalah yang mengakibatkan belum adanya kurikulum PAK Anak di Sinode GKPS. GKPS belum membuat suatu kurikulum PAK Anak karena belum ada ahli PAK yang bertugas secara khusus di sinode GKPS. Bila sudah ada ahlinya, maka kurikulum PAK Anak itu dapat didesain dengan baik. Bahan-bahan dari Sekber UEM dapat tetap dipakai, dikombinasikan dan diolah supaya sesuai dengan pembelajaran PAK Anak yang sesuai dengan konteks GKPS.

Data-data wawancara menunjukkan adanya ketidaksepahaman antara pihak-pihak terkait tentang apa arti ibadah anak atau Sekolah Minggu tersebut. Ada pihak yang menganggap ibadah anak tersebut seperti ibadah orang dewasa, sehingga pengajarannya hanya melalui 
khotbah, yang menggunakan teks Alkitab dari Sekber UEM. Dengan demikian, tidak terbuka kemungkinan adanya kurikulum PAK Anak di GKPS, karena terbentur dengan teks, tema dan tujuan Sekolah Minggu yang ditentukan oleh Sekber UEM. Namun, pihak yang lain menganggap ibadah anak itu sebagai Sekolah Minggu, di mana pengajarannya memang lebih menekankan aspek pengajaran. Dalam pemahaman ini, khotbah dapat disampaikan berdasarkan materi-materi ajar yang dirancang selayaknya kurikulum.

Menurut penulis, ada tiga hal yang dapat dijadikan solusi untuk mengatasi kendala ini. Pertama, ada tim khusus dari gereja-gereja anggota Sekber UEM untuk menentukan ayat khotbah kategorial, yang bekerja lebih awal supaya dapat menentukan nas, tema dan tujuan lebih cepat dan mengirimkannya ke setiap sinode dengan lebih cepat. Dengan demikian, GKPS juga dapat menyusun kurikulum PAK Anak untuk sinode GKPS dengan baik dan matang. Kedua, tetap dibuat kurikulum PAK Anak GKPS yang pelaksanaannya dikombinasikan atau diimprovisasi dengan bahan dari Sekber UEM. Ketiga, khusus untuk kategori Sekolah Minggu, GKPS secara mandiri mendesain kurikulum PAK Anak GKPS. Dengan demikian GKPS dapat menentukan bahan pengajaran Sekolah Minggu, termasuk nas, tema dan tujuan PAK anak sebagaimana identitas dan kebutuhan sinode GKPS.

\section{c. Dinamika Desain Kurikulum PAK Anak berdasarkan Teori Wyckoff}

Dari hasil wawancara kepada kepengurusan tingkat sinodal GKPS, ditemukan konteks GKPS adalah kehidupan yang majemuk, anak hidup dalam kemajuan teknologi, namun anak GKPS tidak boleh lepas dari kebudayaan Simalungun. Konteks budaya Simalungun menjadi salah satu bagian yang diperhatikan oleh pimpinan sinode. Hal ini terkait dengan adanya huruf $\mathrm{S}$ dalam GKPS, Simalungun adalah identitas yang tidak dapat dilepaskan dari GKPS.

Sementara dari hasil wawancara di jemaat GKPS Cengkareng, konteks GKPS yang disampaikan lebih kepada kemajuan teknologi dan bermacam-macam game, lingkungan yang menarik mereka untuk narkoba, mabuk-mabukan, dan godaan lainnya. Hanya satu dari lima responden yang mengatakan pentingnya kurikulum memperhatikan konteks budaya Simalungun. Hal ini mungkin karena jemaat GKPS Cengkareng berada di konteks Jakarta, ibukota negara yang masyarakatnya sangat plural. Anak-anak di perkotaan sudah jauh dari nilai-nilai budaya suku Simalungun. Hal ini sebetulnya menunjukkan bahwa ada masalah lain yang terungkap melalui penelitian ini, yaitu terkikisnya identitas dan nilai-nilai budaya Simalungun di kalangan anak-anak Sekolah Minggu GKPS masa kini.

Sementara menurut hasil wawancara, ruang lingkup untuk kurikulum PAK Anak usia 9-12 tahun adalah tema-tema yang universal dan tema-tema parsial. Tema-tema yang universal antara lain pemahaman tentang siapa Allah, Yesus, Roh Kudus dan Gereja. Tema-tema yang parsial antara lain pemahaman tentang budaya Simalungun, organisasi Gereja GKPS, tugas panggilan sebagai anggota jemaat GKPS. Selain itu, ASM GKPS sangat perlu belajar nilai-nilai Kristiani. Anak dapat mempelajari nilainilai tersebut dari teladan tokoh-tokoh Alkitab, seperti Yusuf yang tulus hati, Raja Salomo yang bijaksana, Ester yang berani, dan lain-lain.

Di pihak lain, menurut hasil wawancara kepada kepengurusan tingkat sinodal GKPS, tujuan pembelajaran PAK Anak di GKPS sudah ditentukan oleh rapat 
gereja-gereja anggota Sekber UEM. Menurut penulis, tujuan tersebut kurang sesuai dengan konteks sinode GKPS. Namun demikian, pimpinan sinode mengatakan ada peluang untuk memasukkan tujuan-tujuan yang khas dengan GKPS dalam PAK Anak di GKPS. Tujuan-tujuan yang khas tersebut adalah supaya anak memiliki iman yang inklusif dan egaliter, memahami budaya Simalungun, cinta kepada Tuhannya, dan akhirnya anak mengasihi komunitasnya atau gerejanya (GKPS). Di pihak lain, PAK diharapkan berjalan untuk meningkatkan kemampuan anak baik kognitif, afektif, maupun psikomotorik. PAK Anak bertujuan untuk meningkatkan spiritualitas anak sekaligus mempersiapkan anak menjadi pengantin Kristus.

Selanjutnya, pembahasan mengenai proses PAK, tidak dapat dilepaskan dengan metode pengajaran. Dari hasil wawancara, ada beberapa metode yang disampaikan oleh responden. Seluruh metode tersebut sesuai dengan teori-teori metode mengajar. Beberapa metode tersebut, antara lain: Buzz Groups, kerja kelompok, panel, simposium, ceramah, tim pendengar, respons sirkuler, research and report, role-playing, permainan, membaca buku, dan lainlain. 93 Proses PAK Anak perlu dilaksanakan dengan kreatif. Anna Craft mengatakan, dalam mengembangkan kreativitas, guru maupun anak-anak perlu memperhatikan hubungan anak dengan lingkungannya. Kreativitas yang bersifat menarik dan melibatkan keseluruhan kelas. Guru perlu membuat tujuan yang jelas kenapa memilih metode tersebut. Pengajaran disesuaikan dengan usia dan

\footnotetext{
${ }^{93}$ Sara Little, Learning Together in the Christian Fellowship (Virginia: John Knox Press, 1956), 3637.

94 Anna Craft, Membangun Kreativitas Anak (Depok: Inisiatif Presisi, 1993).
}

lingkungan naradidik. ${ }^{94}$

Kemudian, mengenai pengorganisasian kurikulum, dalam wawancara terhadap para GSM, pengurus seksi SM dan majelis jemaat di GKPS Cengkareng, bagian ini merupakan bagian yang paling sulit untuk dijawab oleh responden. Namun, pada dasarnya seluruh responden setuju bahwa kurikulum PAK Anak tersebut harus dibuat dengan batasan usia tertentu. Kesulitan yang mereka alami untuk berbicara mengenai pengorganisasian PAK Anak di GKPS adalah hal yang wajar mengingat status mereka sebagai warga dan majelis jemaat biasa. Sementara, menurut hasil wawancara kepada kepengurusan tingkat sinodal GKPS, sebagian menganggap bahwa desain kurikulum sulit diterapkan di sinode GKPS karena terbentur dengan rancangan yang sudah ditetapkan oleh anggota-anggota Sekber UEM. Walaupun demikian, Pimpinan Sinode menyarankan supaya GKPS tetap membuat kurikulum PAK Anak, yang pelaksanaannya dapat dikombinasikan dengan bahan dari Sekber UEM dalam ibadah Anak (Sekolah Minggu). Saran Pimpinan Sinode ini tidak menyalahi teori kurikulum Wyckoff. Menurut Wyckoff, kurikulum PAK dibuat dengan perencanaan untuk melibatkan peserta didik, dengan semua pengalaman pengembangan terorganisir yang beragam dari mereka, dalam studi yang sedang berlangsung di gereja, ibadah, aksi, ekspresi kreatif, persekutuan, dan penatalayanan. 95 Dengan demikian, berdasarkan teori Wyckoff dan harapan dari para responden, maka GKPS sudah dapat mendesain kurikulum PAK Anak di GKPS.

95 D. Campbell Wyckoff, Theory and Design of Christian Education Curriculum (Philadelphia: The Westminster Press, 1961), 144. 


\section{Desain Kurikulum PAK Anak di GKPS Berdasarkan Teori Wyckoff}

\section{a. Pedoman Kurikulum}

Menurut Wyckoff, pedoman kurikulum merupakan bagian penting yang berhubungan dengan dasar-dasar perencanaan kurikulum, untuk digunakan pada tingkat denominasi, sinodal, regional, dan jemaat lokal. Dalam konteks gereja yang membutuhkan kurikulum secara sinodal, diperlukan adanya informasi tambahan khusus dalam kurikulum PAK Anak, yang membantu setiap jemaat lokal di saat menggunakan kurikulum tersebut.
Panduan kurikulum akan menolong gereja dalam menyusun kurikulum PAK-nya. ${ }^{96}$

Kurikulum ini digunakan sebagai panduan pengajaran bagi siapa pun yang mengajar sekolah minggu di Sinode GKPS. Dengan menyadari perbedaan konteks, misalnya antara jemaat di kotakota besar dengan jemaat di pedalaman, materi dapat disampaikan dan diimprovisasi dengan kreatif sesuai dengan konteks Sekolah Minggu di jemaat masing-masing, namun tetap berpedoman pada teks Alkitab, tema dan tujuan pada kurikulum ini.

\section{b. Kurikulum PAK Anak Usia 9-12 Tahun di Sinode GKPS ${ }^{1}$}

\begin{tabular}{|l|l|l|}
\hline A. & Visi & $\begin{array}{l}\text { Menjadikan anak Sekolah Minggu GKPS beriman, tangguh dan takut } \\
\text { akan Tuhan, sesuai dengan ajaran Alkitab melalui PAK pada tahun } \\
\text { 2023. }\end{array}$ \\
\hline B. & Misi & $\begin{array}{l}\text { Meningkatkan spiritualitas anak yang berpusat pada hubungan } \\
\text { yang hidup dengan Allah melalui PAK Anak. } \\
\text { Mewujudkan PAK Anak yang bersikap inklusif lintas golongan } \\
\text { dan meningkatkan persekutuan umat tanpa adanya pandangan } \\
\text { negatif terhadap perbedaan-perbedaan usia, jenis kelamin, dan } \\
\text { status sosial ekonomi. } \\
\text { Melakukan pembinaan agar anak semakin hidup dalam kasih } \\
\text { dan persaudaraan yang akrab dan hangat sebagai tubuh Kristus } \\
\text { Melatih anak memiliki kepedulian melalui praktik melayani. } \\
\text { Melaksanakan proses PAK Anak dengan menggunakan warisan } \\
\text { budaya Simalungun. }\end{array}$ \\
\hline C. & $\begin{array}{l}\text { Nilai- } \\
\text { nilai/Prinsip }\end{array}$ & $\begin{array}{l}\text { Nilai Partisipasi. } \\
\text { Kurikulum ini mengutamakan prinsip pentingnya melibatkan seluruh } \\
\text { pihak dalam melaksanakan PAK Anak, mulai dari anak itu sendiri, } \\
\text { Guru Sekolah Minggu, Pengurus Seksi (Komisi) Sekolah Minggu, } \\
\text { orangtua, pendeta, majelis jemaat, dan seluruh warga jemaat. }\end{array}$ \\
\hline D. & $\begin{array}{l}\text { Anak dapat mengenal Alkitab sebagai Firman Allah. } \\
\text { - Anak dapat menyatakan komitmennya untuk memberikan } \\
\text { maktunya secara teratur untuk mempelajari Firman Tuhan, baik } \\
\text { secara pribadi maupun berkelompok atau dalam persekutuan. }\end{array}$ \\
\hline
\end{tabular}

96 Ibid., 186.

${ }^{1}$ Dalam jurnal ini, hanya dicantumkan kurikulum untuk satu bulan sebagai sampel. Kurikulum yang lengkap dapat dilihat dalam Desain
Kurikulum PAK Anak Usia 9-12 Tahun di Sinode GKPS dengan Menggunakan Teori Wyckoff, Yenni Septiani Purba, tesis, Universitas Kristen Indonesia, Agustus 2019. 


\begin{tabular}{|c|c|c|c|}
\hline & & \multicolumn{2}{|c|}{$\begin{array}{l}\text { - Anak dapat hidup saling mengasihi dan memiliki rasa persaudaraan } \\
\text { yang akrab dan hangat. } \\
\text { - Anak lebih terlatih dan peka untuk peduli kepada sesama, termasuk } \\
\text { kepada lingkungan di luar Gereja. } \\
\text { - } \quad \text { Anak mulai mengenal nilai-nilai warisan budaya Simalungun. }\end{array}$} \\
\hline E. & $\begin{array}{l}\text { Gambaran } \\
\text { Program }\end{array}$ & \multicolumn{2}{|c|}{$\begin{array}{l}\text { Program PAK Anak ini dilakukan untuk Anak Sekolah Minggu di } \\
\text { Sinode GKPS, secara khusus anak usia 9-12 tahun. Materi dari } \\
\text { Kurikulum PAK Anak ini dapat diajarkan dalam ibadah Sekolah } \\
\text { Minggu. Dalam hal ini, perlu kebijaksanaan GSM untuk } \\
\text { mengkombinasikan materi dari kurikulum PAK Anak ini dengan teks } \\
\text { Alkitab dari Sekber UEM. Jika tidak memungkinkan, materi } \\
\text { kurikulum ini dapat disampaikan dalam kelas khusus di luar ibadah } \\
\text { anak. }\end{array}$} \\
\hline F. & $\begin{array}{l}\text { Masa } \\
\text { Pelaksanaan }\end{array}$ & \multicolumn{2}{|c|}{$\begin{array}{l}\text { Kurikulum PAK ini akan dilakukan pada bulan Januari-Desember } \\
\text { 2020. Proses PAK dilaksanakan setiap hari Minggu dalam ibadah } \\
\text { anak pukul 08.00-09.30. Jika tidak memungkinkan, PAK boleh } \\
\text { dilakukan pada hari Minggu sore, atau pada salah satu hari lain yang } \\
\text { sudah ditentukan. Durasi waktu lebih kurang 1-1,5 jam tiap } \\
\text { pertemuan. }\end{array}$} \\
\hline G. & $\begin{array}{l}\text { Penanggung- } \\
\text { jawab }\end{array}$ & \multicolumn{2}{|l|}{$\begin{array}{ll}\text { - } & \text { Tim PAK Anak GKPS } \\
\text { - } & \text { Kepala Departemen Persekutuan } \\
\text { - } & \text { Kepala Departemen Pembinaan } \\
\end{array}$} \\
\hline H. & Pelaksana & \multicolumn{2}{|c|}{$\begin{array}{l}\text { Para Guru Sekolah Minggu dan melibatkan pengurus Sekolah } \\
\text { Minggu, pendeta, penginjil, vikar, warga jemaat berlatar belakang } \\
\text { PAK, majelis jemaat, orangtua, pengajar tamu dan seluruh warga } \\
\text { jemaat. }\end{array}$} \\
\hline I. & Pengajar & \multicolumn{2}{|c|}{$\begin{array}{ll}\text { - } & \text { Pendeta di resort atau jemaat } \\
\text { - } & \text { Penginjil } \\
\text { - } & \text { Vikar } \\
\text { - } & \text { Guru-guru Sekolah Minggu } \\
\text { - } & \text { Warga jemaat berlatar belakang PAK } \\
\text { - } & \text { Majelis Jemaat } \\
\text { - } & \text { Orangtua } \\
\text { - } & \text { Pengajar tamu dari luar gereja (misalnya tenaga medis, psikolog, } \\
& \text { dan lain-lain) }\end{array}$} \\
\hline J. & Naradidik & \multicolumn{2}{|c|}{ Anak Sekolah Minggu GKPS Usia 9-12 tahun. } \\
\hline K. & Tempat & \multicolumn{2}{|l|}{ Jemaat GKPS masing-masing } \\
\hline L. & $\begin{array}{l}\text { Biaya } \\
\text { Pelaksanaan }\end{array}$ & $\begin{array}{l}\text { - Honor dan transportasi } \\
\text { pendeta dan guru/pengajar } \\
\text { - } \text { Biaya fotokopi bahan ajar dan } \\
\text { nyanyian } \\
\text { - } \\
\text { - Biaya pengadaan alat peraga } \\
\text { Biaya perlengkapan } \\
\text { pembelajaran (papan tulis, } \\
\text { spidol, penghapus, flipchart, } \\
\text { dll.) }\end{array}$ & $\begin{array}{l}\text { Ditanggung masing-masing } \\
\text { jemaat }\end{array}$ \\
\hline
\end{tabular}


Volume 3 Nomor 2 Tahun 2019 hal. 27-61

\begin{tabular}{|c|c|c|c|c|c|c|}
\hline No & $\begin{array}{c}\text { Minggu } \\
\mathrm{Ke}\end{array}$ & $\begin{array}{c}\text { Topik } \\
\text { Pelajaran }\end{array}$ & $\begin{array}{c}\text { Tujuan } \\
\text { Pembelajaran }\end{array}$ & $\begin{array}{c}\text { Pokok } \\
\text { Bahasan } \\
\text { dan } \\
\text { Materi }\end{array}$ & $\begin{array}{l}\text { Metode } \\
\text { Mengajar }\end{array}$ & Pengajar \\
\hline 1. & I & $\begin{array}{l}\text { Adam } \\
\text { (90 menit) }\end{array}$ & $\begin{array}{l}\text { Anak dapat } \\
\text { menceritakan } \\
\text { urutan } \\
\text { penciptaan } \\
\text { sampai pada } \\
\text { penciptaan } \\
\text { Adam } \\
\text { - Anak dapat } \\
\text { mengkritisi } \\
\text { teori evolusi }\end{array}$ & $\begin{array}{l}\text { - } \text { Membaca } \\
\text { Alkitab } \\
\text { - Urutan } \\
\text { Penciptaan } \\
\text { - Kejadian } 1\end{array}$ & $\begin{array}{l}\text { Cerita, } \\
\text { Tanya- } \\
\text { jawab, } \\
\text { Diskusi }\end{array}$ & $\begin{array}{l}\text { Pendeta, } \\
\text { melibatkan } \\
\text { orangtua }\end{array}$ \\
\hline 2. & II & $\begin{array}{l}\text { Hawa } \\
\text { (90 menit) }\end{array}$ & $\begin{array}{l}\text { - Anak dapat } \\
\text { mengetahui } \\
\text { bagaimana } \\
\text { terciptanya } \\
\text { Hawa } \\
\text { - Anak dapat } \\
\text { mengakui } \\
\text { kesetaraan laki- } \\
\text { laki dan } \\
\text { perempuan }\end{array}$ & $\begin{array}{l}\text { - Membaca } \\
\text { Alkitab } \\
\text { - Kejadian } 2\end{array}$ & $\begin{array}{l}\text { Cerita, } \\
\text { Tanya- } \\
\text { jawab, } \\
\text { Diskusi }\end{array}$ & $\begin{array}{l}\text { Majelis, } \\
\text { melibatkan } \\
\text { orangtua }\end{array}$ \\
\hline 3. & III & $\begin{array}{l}\text { Adam dan } \\
\text { Hawa } \\
\text { jatuh } \\
\text { dalam dosa } \\
\text { (90 menit) }\end{array}$ & $\begin{array}{l}\text { - Anak mengingat } \\
\text { kisah jatuhnya } \\
\text { manusia dalam } \\
\text { dosa } \\
\text { - Anak menyadari } \\
\text { pelanggaran } \\
\text { terhadap } \\
\text { Firman Tuhan }\end{array}$ & $\begin{array}{l}\text { - } \text { Membaca } \\
\text { Alkitab } \\
\text { - Taman } \\
\text { Firdaus } \\
\text { - Kejatuhan } \\
\text { dalam dosa } \\
\text { - Kejadian } 3\end{array}$ & $\begin{array}{l}\text { Cerita, } \\
\text { Role-play }\end{array}$ & $\begin{array}{l}\text { Jemaat } \\
\text { berlatar } \\
\text { belakang } \\
\text { PAK }\end{array}$ \\
\hline 4. & IV & $\begin{array}{l}\text { Nuh } \\
\text { (90 menit) }\end{array}$ & $\begin{array}{l}\text { - Anak dapat } \\
\text { menyadari dan } \\
\text { mensyukuri } \\
\text { kuasa Allah } \\
\text { atas ciptaan- } \\
\text { Nya }\end{array}$ & $\begin{array}{l}\text { - Sekilas air } \\
\text { bah } \\
\text { - Nuh dan } \\
\text { keluarganya } \\
\text { - Kejadian } 6\end{array}$ & $\begin{array}{l}\text { Cerita, } \\
\text { Pemutaran } \\
\text { film, } \\
\text { research } \\
\text { and report }\end{array}$ & GSM \\
\hline 5. & $\mathrm{~V}$ & $\begin{array}{l}\text { Janji Allah } \\
\text { dengan } \\
\text { Nuh } \\
\text { (90 menit) }\end{array}$ & $\begin{array}{l}\text { - Anak dapat } \\
\text { mengenal dan } \\
\text { menyadari } \\
\text { kuasa Allah } \\
\text { atas ciptaan- } \\
\text { Nya } \\
\end{array}$ & $\begin{array}{ll}\text { - } & \text { Air bah } \\
& \text { surut } \\
- & \text { Kejadian } 8 \\
& \& 9\end{array}$ & $\begin{array}{l}\text { Cerita, } \\
\text { Pemutaran } \\
\text { film } \\
\text { Diskusi }\end{array}$ & Pendeta \\
\hline
\end{tabular}

\section{c. Pedoman Metode}

Panduan ini berupa standar metode yang dapat digunakan untuk kurikulum PAK usia 9-12 tahun. Setiap metode memiliki kelebihan dan kekurangan masing-masing. Panduan metode ini dibuat untuk menolong guru memahami dan mengenali kelebihan dan kekurangan dari setiap metode, sehingga guru dapat memakainya dengan baik. Beberapa 
metode yang dapat digunakan dalam PAK Anak usia 9-12 tahun antara lain: Bercerita, sharing, diskusi kelompok, buzz. group, Studi Kasus, kliping Koran, foto diri, galeri, curah gagasan, asosiasi dan wawancara imajiner.

\section{d. Pedoman Pembelajaran}

Di dalam kurikulum, perlu pula dibuat pedoman pembelajaran. Wyckoff mengatakan bahwa pedoman pembelajaran adalah sumber ide dan bahan untuk dijadikan materi pembelajaran. Pedoman pembelajaran memungkinkan guru untuk membawa naradidik ke dalam proses pembelajaran. ${ }^{98}$ Pedoman pembelajaran ini dapat disusun dalam bentuk suatu buku yang terpisah dari buku kurikulum PAK Anak.

\section{e. Evaluasi}

Evaluasi dapat mencakup evaluasi menyeluruh, dapat pula mencakup evaluasi masing-masing pertemuan. Dalam desain ini, evaluasi secara menyeluruh terhadap kurikulum PAK Anak Usia 9-12 tahun ini dilakukan setelah kurikulum ini dijalankan selama tiga tahun. Kriteria untuk mengevaluasi setiap aspek tidak boleh menyimpang jauh dari tujuan dasar PAK dan konsep konteks, ruang lingkup, dan proses yang terkait dengannya.

Namun demikian, evaluasi terhadap tiap pertemuan dapat juga dilakukan setelah suatu materi pelajaran diajarkan. Evaluasi mingguan ini dilakukan untuk melihat hasil proses belajar mengajar. Dasar dari evaluasi adalah sejauh mana tujuan pembelajaran dapat dicapai. Sebagai contoh, untuk materi pelajaran minggu XVII, tentang tokoh Ayub, evaluasi dapat dilakukan dengan mengajukan beberapa pertanyaan kepada ASM:

- Bagaimana bentuk ketaatan Ayub?

- Bagaimana Ayub menghadapi pergumulannya?

- Apa yang kamu pelajari dari iman Ayub?

Pertanyaan-pertanyaan ini dapat disampaikan setelah guru selesai memberikan keterangan, atau dapat juga disampaikan pada minggu depannya, sebelum memulai pelajaran yang baru.

\section{E. Kesimpulan}

Dari hasil penelitian, diperoleh gambaran bahwa PAK Anak dipahami sebagai pembelajaran nilai-nilai kekristenan dan Alkitab, gereja dan kehidupan untuk anak-anak. PAK Anak perlu memperhatikan perkembangan dan kebutuhan anak sesuai dengan tingkatan usianya. PAK Anak memiliki tujuan yang mulia, yaitu supaya anak mengenali Tuhan, dirinya, sejarah kekristenan, sesama dan lingkungan alam sekitarnya. Secara khusus, untuk anak usia 9-12 tahun, PAK Anak bertujuan untuk membantu anak menemukan jati diri mereka dan memiliki karakter seperti karakter Kristus dan tokoh-tokoh yang baik di Alkitab. PAK Anak usia 9-12 tahun berperan untuk membekali anak-anak usia tersebut dengan dasar-dasar pengetahuan Alkitab sebelum mereka memasuki masa praremaja dan kelas katekisasi sidi. Namun, pelaksanaan PAK Anak di GKPS masih terbatas karena beberapa faktor, antara lain: pertama, belum adanya ahli PAK Anak yang bertugas secara penuh di kepengurusan tingkat sinode. Kedua, adanya ketidakkonsistenan dalam peraturan, rencana dan strategi GKPS mengenai pembagian kelas Sekolah

98 D. Campbell Wyckoff, Theory and Design of Christian Education Curriculum (Philadelphia: The Westminster Press, 1961), 190. 
Minggu. Ketiga, terbatasnya kualitas sumber daya GSM. Penyebabnya antara lain karena masih terbatas GSM yang berlatar belakang ilmu PAK, sementara pembinaan atau pelatihan mengajar bagi mereka juga masih kurang. Keempat, keterbatasan gedung untuk Sekolah Minggu.

Dari hasil wawancara kepada kepengurusan di tingkat sinodal GKPS dan kepengurusan di tingkat jemaat lokal di GKPS Cengkareng, terungkap suatu kenyataan bahwa GKPS belum memiliki kurikulum PAK Anak. Selama ini, buku yang digunakan dalam pengajaran SM adalah Buku Aku Gereja, namun buku itu bukanlah kurikulum. Buku itu tidak sesuai dengan konteks jemaat GKPS, ruang lingkup, tujuan dan proses PAK yang lengkap sebagaimana kurikulum menurut teori kurikulum Wyckoff. Buku Aku Gereja tersebut hanya salah satu komponen dari kurikulum, sebab buku itu hanya buku pedoman pembelajaran sebagai bahan pegangan dan persiapan bagi para guru Sekolah Minggu untuk mengajar Sekolah Minggu. Hal ini bukan berarti GKPS belum pernah membuat menyusun kurikulum PAK Anak. Menurut hasil wawancara, pada periode 2010-2015 sudah pernah dicoba untuk menyusun kurikulum PAK Anak di GKPS. Namun, kemudian kurikulum itu tidak dapat dipakai karena terbentur dengan nas khotbah, tema dan tujuan khotbah yang sudah disepakati bersama dengan Gerejagereja anggota Sekretariat Bersama United Evangelical Mission (Sekber UEM). Oleh karena itu, GKPS wajib menggunakan nas Alkitab, tema dan tujuan yang sudah ditetapkan oleh Gereja-gereja anggota Sekber UEM.

Menurut Wyckoff, desain kurikulum dilakukan dengan menentukan beberapa hal dasar, yaitu: konteks, ruang lingkup, tujuan, dan proses. Dari hasil wawancara ditemukan bahwa konteks
GKPS tidak terlepas dari konteks universal di mana GKPS hidup dalam dunia yang majemuk dan di sekitarnya terjadi perkembangan teknologi yang pesat yang serba digital. Namun demikian, GKPS juga tidak terlepas dari konteks parsial di mana GKPS hidup dalam perhatian untuk memelihara warisan positif dari budaya Simalungun. Oleh karena itu, ruang lingkup, tujuan dan proses PAK juga disesuaikan dengan konteks khas GKPS tersebut. Desain kurikulum PAK Anak usia 9-12 tahun di sinode GKPS sangatlah penting, dengan tujuan untuk membekali anak usia tersebut dengan pondasi iman yang kuat supaya mereka mengenal Tuhan, dunia secara universal, warisan positif dari budaya Simalungun. Dalam prosesnya, anak menjadi pusat dari pembelajaran. Selanjutnya, berdasarkan teori Wyckoff, kurikulum PAK Anak disusun dengan melibatkan banyak pihak, bukan hanya guru-guru dan pengurus sekolah minggu, melainkan juga seluruh orangtua dan warga jemaat secara keseluruhan.

\section{F. Referensi}

Alkitab

Boehlke, Robert R. Sejarah Perkembangan Pikiran dan Praktek Pendidikan Agama Kristen. Jakarta: BPK Gunung Mulia, 2005.

Burgess, Harold William. An Invitation to Religious Education. Birmingham, Alabama: Religious Education Press, 1975.

Bushnell, Horace. Christian Nurture. New Haven: Yale University, 1960.

Carson, Terrance. Beyond Curriculum Management. The ATA Magazine, May/June 1989.

Christiani, Tabita Kartika. Desain Kurikulum Pendidikan Kristiani, dalam Tunas Zaitun: Pendidikan Kristiani Anak di Tengah Keluarga, 
Gereja, Sekolah dan Masyarakat, Nurhayati Girsang, dkk. Jakarta: Adhitya Andrebina Agung, 2017.

Hurlock, Elizabeth B. Psikologi Perkembangan: Suatu Pendekatan Sepanjang Rentang Kehidupan Edisi Kelima. Jakarta: Erlangga: 1980.

Psikologi Perkembangan: Suatu Pendekatan Sepanjang Rentang Kehidupan Edisi Keenam. Jakarta: Erlangga: 1980.

Ismail, Andar. Ajarlah Mereka Melakukan. Jakarta: BPK Gunung Mulia, 2006.

Kadarmanto, Ruth S. Tuntunlah ke Jalan yang Benar: Panduan Mengajar Anak di Jemaat. Jakarta: BPK Gunung Mulia, 2012.

Kristanto, Paulus Lilik. Prinsip dan Praktek PAK Penuntun bagi Mahasiswa Teologi dan PAK, Pelayan Gereja, Guru Agama dan Keluarga Kristen. Yogyakarta: Andi Offset, 2010.

Little, Sara. The Role of the Bible in Contemporary Christian Education. Virginia: John Knox Press, 1962. Learning Together in The Christian Fellowship. Virginia: John Knox Press, 1956.

Makoni, Yurischa Auxiliadora. Kajian Kritis dari Perspektif Teori Kurikulum dan Disabilitas terhadap Isi dan Pelaksanaan Kurikulum Pendidikan Agama Kristen bagi Anak dengan Tantangan Mental di Yayasan Sosial Elisabeth Salatiga. Skripsi. Fakultas teologi Universitas Kristen Satya Wacana Salatiga. 2017.

Nasution, S. Asas-asas Kurikulum. Bandung: Jemmars, t.t.

Pimpinan Pusat GKPS. Susukkara 2018. Pematang Siantar: Kolportase, 2018.
Pimpinan Pusat GKPS. Tata Gereja dan Peraturan-peraturan GKPS. Pematang Siantar: Kolportase, 2013. Pimpinan Pusat GKPS, Visi dan Misi GKPS 2011-2030. Pematang Siantar: Kolportase GKPS, 2013.

Pinar, William F., William M. Reynolds, Patrick Slattery, dan Peter M. Taubman, Understanding Curriculum: An Introduction to the Study of Historical and Contemporary Curriculum Discourses. New York: Counterpoints, 2008.

Pribadi, Benny A. Model Desain Sistem Pembelajaran. Jakarta: Dian Rakyat, 2010.

Prior, John Mansford. Meneliti Jemaat: Pedoman Riset Partisipatoris. Jakarta: Grasindo, 1997.

Seymour, Jack L. Approaches to Christian Education. Dalam Mapping Christian Education: Approaches to Congregational Learning, peny. Jack L. Seymour. Nashville, TN: Abingdon Press, 1997.

Seymour, Jack L. Pendekatan-pendekatan Pendidikan Kristiani. Dalam Memetakan Pendidikan Kristiani: Pendekatan-pendekatan Menuju Pembelajaran Jemaat. Jakarta: BPK Gunung Mulia, 2016.

Sinaga, J.B. Benih yang Ditabur Sedang Bertumbuh: 25 Tahun GKPS Cengkareng, 6 November 19772002. Jakarta: GKPS Cengkareng, 2002.

Smith, P.L. dan T.L. Ragan. Instructional Design: Upper Saddle River. NJ: Merril Prentice Hall, Inc., 1993.

Soekanto, Soerjono. Anak dan Pola Perikelakuannya. Yogyakarta dan Jakarta: Kanisius dan BPK Gunung Mulia, 1985. 
Subagyo, Andreas B. Pengantar Riset Kuantitatif \& Kualitatif: Termasuk Riset Teologi dan Keagamaan. Bandung: Yayasan Kalam Hidup, 2004.

Sugiyono. Metode Penelitian Kuantitatif, Kualitatif dan $R$ \& $D$. Bandung: Alfabeta, 2010. . Metode Penelitian Pendidikan. Bandung: Alfabeta, 2012.

Suhardan, Dadang, dkk. Manajemen Pendidikan. Bandung: Alfabeta, 2009.

Sujanto, Agus. Psikologi Perkembangan. Jakarta: Aksara Baru, 1985.

Sukardi. Metodologi Penelitian Pendidikan: Kompetensi dan Praktiknya. Jakarta: Bumi Aksara, 2009.

Sumiyatiningsih, Dien. Mengajar dengan Kreatif dan Menarik. Yogyakarta: Andi, 2006.

Suparno, Paul. Teori Perkembangan Kognitif Jean Piaget. Yogyakarta: Kanisius, 2001.

Suryabrata, Sumadi. Metodologi Penelitian. Jakarta: Rajawali Press, 1992.

Tanner, D. dan L. N. Tanner. Curriculum Development: Theory into Practice. New York: Macmillan Publishing Co, Inc., 1980.

Tim Penulis. Aku Gereja; Kurikulum dan Bahan Pembelajaran Sekolah Minggu GKPS 2015 Tahun Kemitraan GKPS. Pematang Siantar: Kolportase GKPS, 2015.

Tim Penulis. Aku Gereja; Buku Bahan Pembelajaran Anak Sekolah Minggu GKPS Tahun 2017. Pematangsiantar: Kolportase GKPS, 2017.

Wyckoff, D. Campbell. How to Evaluate Your Christian Education Program.
Philadelphia: The Westminster Press, 1962. . Theory and Design of Christian Education Curriculum. Philadelphia: The Westminster Press, 1960. . The Gospel and Christian Education. Philadelphia: The Westminster Press, 1959.

- The Objectives of Christian Education. Philadelphia: National Council of Churches, 1958.

Sumber Internet:

https://www.koleksiedukasi.tk/2016/02/k onsep-dan-orientasi. Diakses tanggal 14 Mei 2019.

https://staffnew.uny.ac.id/upload/1317828 37/pendidikan/DESAIN+KURIK ULUM.pdf. Diakses 12 Juni 2019. https://kbbi.web.id/anak. Diakes 3 Juni 2019.

https://kbbi.web.id/desain. Diakses 12 Juni 2019.

Wawancara:

Girsang, Paula Vivi, Wawancara, Jakarta, 4 Agustus 2019.

Munthe, Paul, Wawancara, Pematang Siantar, 23 Juli 2019.

Purba, Albert Henrison, Wawancara, Pematang Siantar, 24 Juli 2019.

Purba, Aman Saud, Wawancara, Pematang Siantar, 24 Juli 2019.

Purba, Jhon Sabiden, Wawancara, Pematang Siantar, 22 Juli 2019.

Purba, Martin Rumanja, Wawancara, Pematang Siantar, 25 Juli 2019.

Purba, Yohana, Wawancara, Jakarta, 28 Juli 2019.

Saragih, Jan Hotner, Wawancara, Pematang Siantar, 23 Juli 2019.

Saragih, Jeanne, Wawancara, Jakarta, 29 Juli 2019. 
Saragih, Mariani, Wawancara, Jakarta, 28 Juli 2019.

Saragih, Rianim, Wawancara, Jakarta, 27 Juli 2019.

Saragih, Robert J., Wawancara, Pematangsiantar, 22 Juli 2019.

Saragih, Tri Putri, Wawancara, Pematangsiantar, 23 Juli 2019.

Sinaga, Jarudin Bonar, Wawancara, Jakarta, 27 Juli 2019.

Sumber Jurnal:

Lauterboom, Mariska. Perkembangan Anak dan Remaja serta Implikasinya bagi PAK di Konteks Gereja. Jurnal Theologia UKSW, Salatiga, 2014. 